\title{
Does Spelling Still Matter-And if So, How Should It Be Taught? Perspectives from Contemporary and Historical Research
}

\author{
Steven C. Pan ${ }^{1}$, Timothy C. Rickard ${ }^{2}$, and Robert A. Bjork ${ }^{1}$ \\ ${ }^{1}$ Department of Psychology, University of California, Los Angeles, USA \\ ${ }^{2}$ Department of Psychology, University of California, San Diego, USA
}

This manuscript was accepted for publication in Educational Psychology Review on March 2,2021 . This document may not exactly replicate the final version published in the Springer Nature journal. It is not the copy of record. The final version will be available at: https://dx.doi.org/10.1007/s10648-021-09611-y.

\section{Author Note}

Steven C. Pan (iD) https://orcid.org/0000-0001-9080-5651

We have no known conflict of interest to disclose.

Author contact information (e-mail) is as follows: stevencpan@ucsd.edu (Steven C. Pan), trickard@ucsd.edu (Timothy C. Rickard), and rabjork@psych.ucla.edu (Robert A. Bjork).

Correspondence regarding this manuscript should be addressed to Steven C. Pan, Department of Psychology, University of California, San Diego, La Jolla CA 92093-0109. Email: stevencpan@ucsd.edu 


\begin{abstract}
A century ago, spelling skills were highly valued and widely taught in schools using traditional methods, such as weekly lists, drill exercises, and low- and high-stakes spelling tests. That approach was featured in best-selling textbooks such as the Horn-Ashbaugh Speller of 1920. In the early $21^{\text {st }}$ century, however, skepticism as to the importance of spelling has grown, some schools have deemphasized or abandoned spelling instruction altogether, and there has been a proliferation of non-traditional approaches to teaching spelling. These trends invite a reevaluation of the role of spelling in modern English-speaking societies and whether the subject should be explicitly taught (and if so, what are research-supported methods for doing so). In this article we examine the literature to address whether spelling skills are still important enough to be taught, summarize relevant evidence, and argue that a comparison of common approaches to spelling instruction in the early $20^{\text {th }}$ century versus more recent approaches provides some valuable insights. We also discuss the value of explicit spelling instruction and highlight potentially effective ways to implement such instruction, including the use of spelling tests. Overall, our goals are to better characterize the role of spelling skills in today's society and to identify several pedagogical approaches—-some derived from traditional methods and others that are more recent—-that hold promise for developing such skills in efficient and effective ways.
\end{abstract}

Keywords: spelling; evidence-based learning; explicit instruction; incidental instruction; literacy; testing 


\section{Does Spelling Still Matter-And if So, How Should It Be Taught? Perspectives from Contemporary and Historical Research}

One of the most successful spelling textbooks of the $20^{\text {th }}$ century, the Horn-Ashbaugh Speller, began its print run in 1920. Written by Ernest Horn and Ernest Ashbaugh, both professors of education at the University of Iowa, the postcard-sized textbook represented the state-of-the-art (at the time) in evidence-based spelling instruction. The Speller contained gradeappropriate lists totaling 4,578 words and prescribed a daily routine of testing, writing, and word study exercises. Over multiple editions, it became a bestseller in the U.S. and was, for at least 25 years (Ruan \& Griffiths, 2007), a constant companion to millions of $1^{\text {st }}-8^{\text {th }}$ grade students.

A century later, spelling textbooks continue to be published, but many educators no longer regard them as essential. In fact, in recent years a growing number of schools in the U.S. and at least several schools in the U.K. have deemphasized or eliminated traditional methods of explicit spelling instruction - that is, pedagogical activities that focus on the deliberate teaching of spelling—such as weekly word lists and spelling tests (Barker \& Puente, 2013; BBC News, 2008; Gentry, 2011; Mellon, 2009; Murray, 2015; Shalash, 2011; see also Fry, 2015; Sultan, 2010; Woo, 1997). Approximately 250 schools and counting have implemented these changes (for a partial list, see Table 1). Moreover, measures of spelling ability no longer appear on standardized tests in some U.S. states, and standalone assessments of spelling skills have also been phased out in other cases (Denn, 2019). Some observers even suggest that technological innovations have rendered spelling skills obsolete (Klein, 2016; Trubek, 2012). These developments raise important questions, including: Does spelling still matter in the $21^{\text {st }}$ century, and if so, should schools continue teaching it? Are historically prominent approaches to spelling instruction, including a dedicated spelling curriculum and the use of spelling tests as promoted by the Speller and other textbooks, still pertinent today? Or are those practices truly obsolete? 
In this article, which draws from the vast spelling literature and highlights both contemporary and historical perspectives, we examine relevant research in search of answers.

\section{Are Spelling Skills Still Important to Learn?}

The Speller advised teachers to introduce the topic of spelling thusly: "Begin by pointing out the importance of spelling. Give cases if possible, where people have been discredited because of spelling errors in letters." (E. Horn \& Ashbaugh, 1920, p. xi). That advice reflected a societal approbation of the ability to spell—which at the time could be defined as the capacity to write words that conform to the orthography of a given language — that had been pervasive since at least the $16^{\text {th }}$ century and grew in importance with the rise of the printing press and printed books (Venezky, 1980; e.g., Coote, 1596; Webster, 1783). In the last decade, however, skepticism about the value of spelling skills, including from instructors, school administrators, commentators, and members of the general public, has become increasingly prevalent. Among claims used to justify such skepticism, three of the most common are: (a) incorrect spelling is no longer penalized on many standardized tests (Denn, 2019); (b) widely-used technologies that automate the spelling process, such as spellcheck and autocorrect, reduce the need to be a good speller (Stewart, 2013); and (c) the proliferation of different ways to spell many frequently used words, as has occurred via text messaging, email, and other casual forms of communication, obviates the very concept of correct spelling (Trubek, 2012). Perhaps not coincidentally, the propagation of these claims coincides with the decline of spelling instruction in some schools.

The devaluation of spelling skills is exemplified in recent quotes published in education magazines and in the popular press. For instance, in a 2013 Times Educational Supplement interview, a professor of educational technology opined, “The emphasis on grammar and spelling, I find a bit unnecessary because they are skills that were essential maybe a hundred years ago but they are not right now," and moreover, "my phone corrects my spelling so I don't 
really need to think about it" (Stewart, 2013). Regarding job resumés, a Financial Times columnist claimed in 2014 that "typos and spelling mistakes don't really matter" except "only if I were trying to hire a proofreader" (Kellaway, 2014). An opinion piece in Wired magazine even asserted that "English spelling is a terrible mess anyway, full of arbitrary contrivances and exceptions that outnumber rules," and hence "it would be far better to loosen our idea of correct spelling” (Trubek, 2012; cf. Koerner, 2012).

Throughout much of the $20^{\text {th }}$ century, such comments would likely have been met with skepticism and even horror (with the possible exception of complaints about the irregularity of English spelling, which Noah Webster, Theodore Roosevelt, and others attempted to address). Among most contemporary reading and other literacy researchers, the importance of spelling remains undisputed. Recently, however, not only have comments expressing skepticism about the value of spelling received widespread circulation, but in many cases those comments have gone completely unchallenged. In tandem with that attitudinal shift, the problem of subpar spelling skills remains fairly widespread: Elementary school teachers still commonly report spelling difficulties among their students (e.g., $27 \%$ of students according to a national U.S. survey conducted by Graham et al., 2008). Some instructors have also noted increases in errorprone and informal styles of writing among their students, particularly in emails (Epstein, 2006; Flaherty, 2019; Glater, 2006). That trend is partially substantiated by corpus data: Constantinou et al. (2020) and Constantinou and Chambers (2020) found evidence of decreasing formality in writing style (e.g., inconsistent tense use) and a greater use of non-standard English (e.g., lack of subject-verb agreement) in U.K. student writing samples collected in 2014 versus 2004. The increased use of electronic methods of communication wherein correct spelling and formal writing style are not required may also be a factor: Survey data indicate a shift toward informal writing styles among U.S. teenagers (Lenhart et al., 2007), although such shifts have not yet 
supplanted traditional approaches to writing (Lunsford \& Lunsford, 2008). In an effort to forestall a further deterioration of writing standards, some institutions have recently developed "netiquette" guidelines with reminders to use proper grammar and correct spelling in electronic communication (e.g., Arizona State University, 2020; Iowa State University, 2015; Oregon Institute of Technology, 2018).

\section{Psychological Appraisals and Consequences of Spelling Errors}

Contrary to the assertions of skeptics, an examination of research on how human beings view spelling errors suggests that the longstanding approbation of spelling skills remains justified. First, consider the employment sector: In industries ranging from accounting to technology services, spelling and other writing skills are frequently used and prized by recruiters (e.g., Christensen \& Rees, 2002; Martin-Lacroux \& Lacroux, 2016; see also National Commission on Writing, 2004, 2005). Spelling skills may also be considered in promotion decisions. Accordingly, the presence of spelling errors in resumés and other application materials, which are often quickly scanned during an initial screening stage, can be devastating: In a survey conducted by human resources firm Adecco (2013), 43\% of recruiters listed spelling errors as sufficient grounds for immediate rejection. Additionally, in experiments wherein professional recruiters rated application forms, the presence of spelling errors significantly damaged applicants' chances at being shortlisted (e.g., Martin-Lacroux \& Lacroux, 2016). Spelling errors can also substantially worsen recruiters' impressions of a candidate's professional capabilities (Martin-Lacroux, 2017), including assessments of their level of attention to detail and concern about the quality of their writing (Barker \& Puente, 2013). Thus, contrary to claims that spelling skills are rarely considered in the workplace and/or should be regarded as unimportant (Kellaway, 2014), data on hiring and promotion practices suggest that such skills remain valuable. 
Spelling errors can also be costly for companies and organizations. If a potential customer notices even one spelling error in an advertisement, for example, then their interest in the advertised business drops (Mozafari et al., 2019). If an online review contains spelling errors, then readers form a less positive impression of the company being reviewed (Cooper et al., 2020), although the review is also regarded as less credible. Spelling errors on commercial websites can negatively impact sales and consumer attitudes (Everard \& Galletta, 2005; Stiff, 2012), with (according to some estimates) up to half of sales lost because customers doubt the credibility of incorrectly spelled information (e.g., Coughlan, 2011). Relatedly, security experts commonly advise treating websites and emails with spelling errors as potentially fraudulent (e.g., Consumer Reports, 2012). Companies and other organizations have a vested interest, therefore, in prioritizing correct spelling in customer interactions and in promotions of products or services that they make or market.

More broadly, spelling errors often negatively impact the perception of writers and their writing. In fact, Varnhagen (2000) found that even $2^{\text {nd }}, 4^{\text {th }}$, and $6^{\text {th }}$ grade students gave lower quality ratings and rated writers more poorly after reading a story that contained spelling errors, as opposed to a story that contained no such errors. Negative ratings increased with both age and grade, suggesting that correct spelling is increasingly valued as individuals mature. Kreiner et al. (2002) found that the presence of spelling errors caused adults to give lower ratings of authors' writing abilities, and in some cases, lower ratings of authors' intellectual ability as well. Further, when told that a writer had access to spellcheck software, readers were still more likely to blame the writer than spellcheck for any spelling errors (Figueredo \& Varnhagen, 2005). Hence, the responsibility for producing error-free text remains with the writer. Spelling also matters online: In web forum discussions, misspelled posts are more likely to be questioned than are correctly spelled posts, with such errors also thought to decrease the credibility of the author (Jeong et al., 
2017; see also Liu, 2004; Morris et al., 2012). These findings all suggest that correct spelling confers a "halo effect"- that is, beyond simply aiding a writer's ability to communicate effectively, a lack of spelling errors can improve perceptions of their credibility and qualifications_-and, conversely, the presence of such errors can lower such perceptions.

Among educational assessments, the Scholastic Achievement Test (SAT) and other major standardized tests do not assess spelling or penalize spelling errors. Hence, spelling is arguably unimportant when taking such tests. However, the current U.S. Common Core State Standards feature specific spelling benchmarks from grade 3 onwards (Gentry, 2013; Reed, 2012), thus giving schools cause to evaluate spelling skills, and some states have added penalties in their standardized tests for incorrect spelling (e.g., the Florida Comprehensive Achievement Test began doing so in 2012). Moreover, 11-year old students in the U.K. are required to take the Spelling, Punctuation, and Grammar (SPaG) test (Gov.uk, 2013). Thus, despite a lack of spelling assessments in some school districts and on some standardized tests (which complicates efforts to systematically track spelling ability over time), spelling still matters in various educational settings where it is directly evaluated.

\section{Spelling Skills in the Era of Spellcheck, Autocorrect, and Text Messaging}

Although spelling errors have historically ranked at or near the top of lists of the most common mistakes that writers make (Johnson, 1917, Hodges, 1941), the advent of spellcheck software, which highlight spelling errors and can suggest correctly spelled replacements, and autocorrect or autocomplete software, which attempts to automatically replace misspellings with correctly spelled words, appears to have changed the nature of those errors. Connors and Lunsford (1988) analyzed over 3,000 student papers from across the U.S and reported that the most common type of mistake_-exceeding all others by approximately $300 \%$-involved incorrectly spelled words. That result was consistent with findings stretching back many 
decades. Two decades later, however, a follow-up study by Lunsford and Lunsford (2008) found that the overall rate of writing errors (of all types) had not substantially changed (i.e., 2.45 errors per 100 words in 2008, versus 2.26 and 2.11 errors per 100 words in 1988 and 1917 , respectively), but the prevalence of incorrectly spelled words had fallen to $5^{\text {th }}$ place among all error types. In its place, the most common error was one that spellcheck does not typically catch—namely, correctly-spelled, but incorrect, words (e.g., homonyms such as brake in place of break). These errors comprised nearly $14 \%$ of all mistakes and occurred not only when writers depend solely on spellcheck (that is, without performing additional manual checks), but also when writers select correctly spelled but inappropriate words from the options provided by spellcheck (relatedly, a corpus analysis by Mitton (1987) found that over one-quarter of students' spelling errors consisted of otherwise correctly spelled, but inappropriate, words). These findings reveal that spellcheck and autocorrect, though clearly capable of eliminating typos and other obvious spelling errors, are not foolproof. Further, in some studies the upper bound of spellcheck efficacy has been about 80\% (e.g., MacArthur et al., 1996; see also McNaughton et al., 1994), thus leaving it up to the writer to address the remaining $20 \%$ of spelling errors. Lunsford and Lunsford's (2008) study also highlighted several other error types that software-based writing aids commonly miss and can even exacerbate, including the incorrect use of proper nouns, the incorrect capitalization of words (possibly due to auto-capitalization functions), and errors in punctuation, apostrophes, dashes, and quotation marks. It is also important to note that in cases of extreme misspellings, spellcheck and autocorrect may be unable to identify the intended word. Thus, although the widespread use of software-based writing aids has indeed reduced the rate of obvious misspellings and other types of mistakes, those aids do not guarantee appreciably better writing. Rather, writers now need to not only attend to the errors that those aids do not catch, but also to the unique types of errors that such 
aids may generate. A heavy reliance on spellcheck software may even lull writers into a false sense of security, resulting in less vigilance to errors (e.g., Galletta et al. 2005). Although improved programs that integrate contextual data, voice recognition, or machine learning (Greer et al., 2016) promise to attain better accuracy—perhaps in the not-too-distant future-and the use of some types of spellcheck software might even lead to incidental learning of spelling skills (e.g., Lin et al., 2017), the research currently available indicates that suggestions to relegate the responsibility for correct spelling entirely to software-based writing aids are misguided.

The widespread use of text messaging, email, and other forms of social media (e.g., Twitter) has also resulted in a growing array of textisms - that is, abbreviations, acronyms, pneumonic devices, and other words that are commonly used in text messages, tweets, and informal emails (e.g., IMHO, plz)—entering into the mainstream vernacular. This trend has led some observers to worry that new modes of communication are causing spelling skills to deteriorate (for discussion see Kemp et al., 2014). Others have even proposed reconceptualizing the importance of correct spelling to accommodate the diversity of textisms and other neologisms (e.g., Trubek, 2012). However, the emerging research literature on text messaging and spelling suggests that fears about negative impacts on spelling ability are, thus far, largely overstated. Drouin and Davis (2009), Kemp (2010), and Massengill Shaw et al. (2007) found that the use of textisms was not predictive of spelling ability in adults; similarly, Plester et al. (2009) found no significant association of textism use with spelling ability in elementary school children. Further, Drouin (2011) and De Jonge and Kemp (2012) reported positive and negative correlations, respectively, between the frequency of text messaging use and spelling ability in adults. Overall, these studies suggest that there is not a consistently negative influence of textisms on spelling skills.

In addition, it appears that most writers generally limit their use of textisms to more 
casual forms of writing. Lunsford and Lunsford (2008) found no indication of textisms slipping into formal prose in student writing samples, although textisms occasionally appeared in notes or in comments. Similarly, Rosen et al. (2010) found that young adults commonly report using approximately 8-10 textisms daily in their text messages, but when tasked with writing both formal and informal essays, the vast majority do not use any textisms (see also Tagliamonte \& Denis, 2008). In a nationwide U.S. survey (Lenhart et al., 2007), however, over 25\% of teenagers admitted to incorporating textisms into their school writing. Overall, it appears that the increased use of new modes of communication and the proliferation of textisms and other casual orthographic forms, while having some influences on writing behavior, have not (as of yet) materially reduced adherence to conventional spelling. Moreover, despite some indications that writing is becoming less formal (e.g., Constantinuou et al., 2020; Constantinou \& Chambers, 2020; Lenhart et al., 2007), the existence of standard, universally-agreed upon spellings remains a cultural norm that, in the service of clarity, is generally expected in most writing and may be even more important in the digital era (Koerner, 2012). That expectation remains the case for traditional written communications (e.g., corporate and other official correspondence), and now also applies in various online venues (e.g., news websites, blog posts, and e-mails).

\section{Evidence of Links Between Spelling, Reading, and Writing Skills}

Research on links between spelling, reading, and writing skills provides further insights into the importance of spelling skills, although conflicting evidence complicates interpretation. ${ }^{1}$ First consider reading. Misspellings can make text more difficult to read (e.g., Oelke et al., 2012), whereas improvements in spelling ability are associated with enhanced reading skills (for

\footnotetext{
${ }^{1}$ A substantial portion of the research literature on literacy skills focuses on students with learning disabilities or difficulties. This article focuses on evidence from normally developing learners. The interested reader may wish to consult relevant review articles (e.g., Galuschka et al., 2020) for further information.
} 
discussion see Moats, 2005/2006). A recent meta-analysis of 20 experimental and quasiexperimental K-12 classroom studies (Graham \& Santangelo, 2014; see also Graham \& Hebert, 2010) comparing spelling instruction against no instruction or other learning interventions that did not focus directly on spelling (e.g., Kirk \& Gillon, 2009; Ouellette \& Sénéchal, 2013; Rieben et al., 2005) found that spelling instruction was associated with improved reading skills. However, the conclusions of the meta-analytic literature on spelling-focused instruction and reading skills have recently been criticized on methodological and interpretative grounds (for discussion see Bowers, 2020; Fletcher et al., 2020), which heightens the need for more research to verify the efficacy of such instructional methods. Moderate-to-high correlations of $r=0.5-0.9$ between spelling and reading test scores have also been observed across multiple studies (e.g., Ehri, 1987; Townsend, 1947; for discussions see Graham et al., 2002; Rayner et al., 2001; Shankweiler \& Lundquist, 1992), indicating potential links between the two skill domains, but a causal relationship cannot be inferred from such data. It is also more common for skilled readers to be poor spellers than for poor readers to be highly proficient spellers (Bosman \& Van Orden, 1997; Frith, 1978), which implies an asymmetrical relationship between spelling and reading.

Overall, there are some indications that spelling skills can impact reading ability, but the precise nature of such impacts and the extent to which instruction in spelling impacts reading ability remain to be fully established.

With respect to writing, poor spelling ability has been hypothesized to impair the composition process by taxing cognitive resources and interfering with higher order skills that are needed to produce well-written prose (Graham, 1999). Accordingly, if students have difficulties with spelling, they may then be impaired in developing broader writing skills (Graham et al., 2002). A recent meta-analysis of six empirical studies of the effects of spelling instruction on writing ability (e.g., Berninger et al., 2002; Graham \& Harris, 2005; Sussman, 
1998) however found that such instruction yielded modest but not statistically significant improvements (Graham \& Santangelo, 2014). Thus, although spelling skills may impact writing ability, evidence for knock-on effects of spelling instruction on writing skills is not strong (even before taking into account the aforementioned methodological criticisms of such meta-analytic data). Additionally, as with spelling and reading skills, moderate-sized positive correlations between spelling and writing skills of $r=0.4-0.5$ have been observed (e.g., Graham, 2000, Graham et al., 2007; see also Abbott et al., 2010; Puranik \& AlOtaiba, 2012; Rankin et al., 1993), but again those correlations do not necessarily indicate a causal relationship. In summary, although there are indications that spelling skills can influence reading and possibly writing skills, the extent of that influence needs further investigation (see also Graham, 2000).

Overall, an abundance of research confirms that spelling remains important in the $21^{\text {st }}$ century. As summarized in Table 2, that importance stems not just from the potential influence of spelling skills on reading and writing skills, but also from the vital role of spelling in securing employment, in business, and in affecting the perception of writers and their writing. Despite sociocultural, technological, and some attitudinal changes, those characteristics of spelling have not changed substantially in recent years. Moreover, technological innovations have not eliminated the need to learn to spell, nor-outside of texting and other casual modes of communication — have they irrevocably changed the way that words are spelled. Based on these findings, the recent trend towards abandoning or minimizing spelling instruction, which has alarmed some researchers, parents, and observers (e.g., Barker \& Puente, 2013; Gentry, 2011; 2017; Petersen, 2010; "Spellbound", 2010), appears to be misguided.

\section{Should Spelling Skills Still Be Taught?}

Given that spelling skills evidently remain important, the question follows: Should spelling still be taught in schools? That is, should class time still be devoted to spelling 
instruction, perhaps including the memorization of difficult words, learning spelling rules, charting the etymology of words, or other spelling-focused activities? Historically, elementary school teachers have devoted substantial amounts of class time to spelling. For instance, Graham's (2008; see also Fresch, 2007; Hillerich, 1982) nationwide survey of spelling instructional practices in U.S. elementary schools found that instructors spend an average of almost 90 min per week on the subject (which, incidentally, exceeds the 15 min daily amount that has long been recommended in the spelling literature; e.g., E. Horn, 1919; Rice, 1897). Devoting instructional time to spelling might seem sensible given that English is one of the world's most irregularly spelled languages (Vangelova, 2015). In contrast with other alphabetic languages, such as Italian and Finnish, wherein each letter represents just one sound, the 26 letters of the English alphabet can be used to represent 44 different sounds and create over several hundred letter combinations (Gentry, 2010). Moreover, learners typically need to master 6,000-12,000 words to write effectively in English (Graham, 2000; Hanna et al., 1996). As discussed next, however, it is no longer the case that all elementary school teachers devote instructional time specifically to the subject of spelling.

\section{Explicit Versus Incidental Spelling Instruction}

Currently, elementary school teachers commonly use either of two primary approaches to teaching spelling (Graham, 1983, 2008): (a) explicit instruction (also known as the spelling-istaught, formal, or systematic approach), wherein some portion of instructional time is focused specifically on spelling; or (b) incidental instruction (also known as the spelling-is-caught, informal, or naturalistic approach), wherein little-to-no instructional time is specifically used and spelling is instead learned via reading and writing activities (and in some situations, correct spellings are modeled by the instructor and/or discussed in the context of "teachable moments" that arise during those activities; for discussion see Edelsky, 1990). From an instructor's 
standpoint, explicit instruction typically entails pre-planned instructional activities wherein spelling is the sole focus (e.g., word study exercises using weekly assigned spelling lists), whereas implicit instruction might involve inserting spelling words into lessons involving other topics (e.g., history and science) and discussing those words in the context of those lessons (for further discussion of different instantiations of the two approaches, see Treiman \& Kessler, 2014). ${ }^{2}$ Importantly, there are a wide variety of ways in which the explicit and incidental approaches could be implemented (some of which are discussed later in this article). In yet other cases, a combination of the two approaches is used: For instance, when several elementary schools in Lee County, Florida overhauled their spelling curriculum to eliminate traditional methods, including all spelling tests, school officials suggested that the learning of spelling would be woven throughout all academic subjects, including science and social science units, via a mix of explicit and incidental methods (Fry, 2015).

The explicit approach has been, for more than four centuries, the most common way that spelling is taught. It dates at least as far back as the publication of the first known spelling textbook (Coote, 1596). The incidental approach has existed for well over a century and gained popularity during the 1970s when prominent psycholinguists (e.g., Chomsky, 1971; Zutell, 1978) interpreted the finding that children's "invented spellings" (i.e., incorrectly spelled words that they come up with on their own) eventually give way to more accurate spellings as an indicator that human beings have an innate capacity for developing spelling skills on their own (Read, 1971; see also Chomsky, 1971), including via statistical learning (Treiman \& Kessler, 2014). The incidental approach also addressed some instructors' concerns that traditional spelling

\footnotetext{
${ }^{2}$ For discussion of yet other approaches to spelling instruction that are not addressed in detail here, such as developmental spelling approaches, see Johnston (2000) and Schalgal (2002).
} 
instruction is too "siloed" (that is, disconnected from reading and writing activities), which has been a recurring theme in anecdotal reports (e.g., Gill \& Scharer, 1996). Proponents and detractors of both approaches have debated their relative merits for many decades (Woo, 1997). Since the 1970s, however, there has been a noticeable trend towards dropping explicit instruction in favor of incidental instruction, particularly in some U.S. school districts (see Table 1), and that trend appears to have accelerated in recent years (e.g., Barker \& Puente, 2013; Fresch, 2002, Gentry, 2010; Mellon, 2009; Murray, 2015; Schalgal \& Schalgal, 1992; Shalash, 2011).

\section{The Case for Explicit Spelling Instruction}

Graham (2000) conducted an in-depth review of the research literature addressing explicit versus incidental spelling instruction. Differences across studies in experimental design, outcome assessment, and control for confounding variables complicated interpretation. There was also insufficient evidence to thoroughly evaluate the merits of either approach. Nevertheless, the tentative conclusion was that explicit instruction should not be replaced with incidental methods. Evidence favoring explicit instruction included: (a) reading can yield some incidental learning of spelling, but such learning is modest compared to explicit instruction; and (b) writing yields modest and inconsistent improvements in spelling ability. It was concluded the incidental instruction should at most supplement explicit instruction (Graham, 2000).

More recent reviews of the literature have also affirmed the efficacy of explicit spelling instruction (e.g., Joshi et al., 2008; Schlagal, 2002; Treiman, 2018). For instance, Graham and Santangelo (2014) meta-analyzed 23 studies that directly compared the explicit and incidental approaches, including studies that were not available for earlier reviews; explicit instruction was reported to increase spelling skills relative to incidental instruction by an effect size of Hedges' $g$ $=0.43,95 \%$ confidence interval $(\mathrm{CI})[0.25,0.60]$. Further, explicit instruction was reported to enhance spelling skills over no instruction by $g=0.54,95 \%$ CI $[0.39,0.70]$, and it was observed 
that additional explicit instruction led to greater improvements in spelling skills (for related meta-analytic findings involving students with learning difficulties, see Galuschka et al., 2020).

Advantages of explicit spelling instruction have also been observed in authentic educational settings. In 1987, the California Board of Education directed all public schools in the state to switch from explicit to incidental or "literature-based" instruction (Woo, 1997; see also Krashen, 2002). Motivated by the increasing popularity of "holistic" approaches to literacy, that switch served as an early test case for the efficacy of the incidental approach (Gentry \& Graham, 2010). Spelling disappeared from required textbook lists and schools switched to addressing the subject via reading and writing activities (Woo, 1997). By the early 1990s, the switch to incidental instruction had been widely blamed for a statewide drop in student reading scores (Colvin, 1995; although for an alternative interpretation, see Krashen, 2002), and reports of incorrectly-spelled student letters and essays-including a publicized case wherein over two dozen $8^{\text {th }}$ grade students in Middletown, California produced nearly as many incorrect spellings of the word "vandal" in letters sent to a local newspaper-led to a public outcry (Woo, 1997). Subsequently, state officials backtracked, endorsing a back-to-basics approach and the restoration of explicit spelling instruction (a practice that some teachers, frustrated with an approach that they believed was ineffective, had already begun to implement independently). The California state legislature codified that recommendation into law in 1996 (Gentry \& Graham, 2010; Woo, 1997). Afterwards, scores on the spelling portion of the Stanford Achievement Test (SAT-9) exhibited incremental year-on-year gains at every assessed grade level, increasing from an average percentile rank of 36-42\% in 1998 to $41-55 \%$ by 2002 (California Department of Education, 1998, 1999, 2000, 2001, 2002).

Test cases such as the apparent failure of the incidental approach in California reinforce the conclusion that incidental instruction/learning results in poorer spelling skills than does 
explicit instruction. With school districts in other U.S. states recently making the same switch to incidental instruction that California once attempted, it appears that history is on the verge of repeating itself. Another potential problem with incidental instruction is that assessments for spelling ability are often dropped with that approach, making the efficacy of such instruction difficult to assess and track (Denn, 2019).

In 1919, the Speller's first author proposed as a first principle of effective spelling instruction, "Do not depend solely on the incidental teaching of spelling" (E. Horn, 1919, p. 53). In support of that principle, it was argued that any class time that might be saved via incidental instruction would not translate to improved spelling skills, and that even carefully planned methods of supposedly incidental instruction, as opposed to a haphazard but more genuinely incidental approach, would still be less effective than explicit instruction. A century later, that principle appears to have been proven correct. Ultimately, the advantage of explicit over incidental instruction may stem from the fact that it enables teachers to ensure that their students receive training that actually builds spelling proficiency, rather than waiting for, or attempting to engineer, teachable moments.

\section{Are Traditional Approaches to Spelling Instruction Still Valid?}

Given the evidence that spelling should be explicitly taught, at least in part, the question follows: What methods of spelling instruction are the most effective? That question has occupied researchers since at least the late $19^{\text {th }}$ century, when Joseph Mayer Rice published the first scientific investigations on the topic (Rice, 1897; see also Mann, 1839), and has given rise to one of the most extensive research literatures in all of the language arts (Allred, 1977). ${ }^{3}$

\footnotetext{
${ }^{3}$ A non-exhaustive list of relevant reviews and related articles includes Allred, 1966, 1984; Cook, 1957; Fitzsimmons \& Loomer, 1977; Graham, 1983; E. Horn, 1919, 1954; Joshi et al., 2008; Mazzio, 1987; Reed, 2012; Schalgal, 2001, 2002; Simonsen \& Gunter, 2001; Treiman, 2018; and Wallace, 2006.
} 
Although a comprehensive treatment of that research is beyond the scope of this article, a comparison of spelling research and recommendations from the early-to-mid $20^{\text {th }}$ century with more recent developments reveals four important patterns: (a) shifting views about optimal methods of explicit spelling instruction, (b) changes in the definition of spelling skills, (c) discrepancies between research-based recommendations and common educational practices, and (d) recent debates pertaining to the use of spelling tests. Using the Speller as an example of a traditionally popular approach to spelling instruction, those patterns are discussed next.

\section{Revisiting the Horn-Ashbaugh Speller}

In 1920, the Speller espoused a curriculum wherein spelling was learned on a daily basis using lists assigned weekly. That approach drew from the available spelling literature and empirical research conducted by the first author (key findings of which had been summarized in a book chapter (E. Horn, 1919) published a year prior). As detailed in Table 3, the Speller had teachers introduce a word list every Monday and then administer a pretest on that list. On Tuesday, students studied and practiced the words that they had missed on the pretest. A diagnostic test on Wednesday measured the progress that had been made, and after students engaged in additional practice on Thursday, another diagnostic test occurred on Friday. That cycle repeated each week with a new word list. Throughout, students were expected to keep a notebook wherein they documented their progress, wrote down challenging spelling words, and described any spelling difficulties that they had experienced in their own writing activities. That notebook bears resemblance to those still used in some primary schools for math and other subjects (e.g., Numeracy Ninjas, 2020) and was intended to foster the development of a "spelling conscience" (i.e., a sense of responsibility for correct spelling), pride in one's spelling ability, and improved motivation to become a better speller (E. Horn \& Ashbaugh, 1920; see also Hillerich, 1977). 
Besides introducing a new word list each week, the Speller also called for the periodic review of previously learned spelling words. On each Wednesday and Friday test, not only were the words from that week's list assessed, but the words from a list that had been assigned one month before were assessed as well. Students were supposed to include any of those "older" words that they had missed on such tests in their practice activities. Additionally, difficult words were to be reviewed at the start of each school year. A contemporary view of these activities is that they constituted implementations of distributed practice —-that is, learning across multiple sessions spread apart in time (it should also be noted that the Monday-Wednesday-Friday pretesting and posttesting schedule could be classified as another instantiation of distributed practice). The benefit of distributed practice for learning, which is also known as the spacing effect, is now considered to be one of the most robust of all learning phenomena (for a review, see Cepeda et al., 2006; for related discussions see Ebbinghaus, 1885; Treiman \& Kessler, 2014). Distributed or "spaced" practice can improve students' ability to remember information and apply skills across a wide range of conditions (e.g., Bahrick et al., 1993; Rohrer et al., 2015). Hence, the Speller was arguably a pioneer, or at least an early adopter, of one of the most potent learning techniques.

In addition to thrice-weekly diagnostic tests, the Speller had students use practice testing to learn spelling. Specifically, after studying a word and attempting to visualize it, students were directed to cover it, attempt to write it from memory, and then check for correctness (Table 3). That process, which was to be repeated three times per word, reflected Horn's belief that testing with corrective feedback constitutes the "most fruitful single learning activity (per unit of time) that has yet been devised" (E. Horn, 1954, pp. 17-18). That assertion has since been supported by various research findings over several decades. In fact, it is now well-established among cognitive and educational psychologists that low-stakes practice testing, or retrieval practice, 
can serve as a more potent "memory modifier" than non-retrieval studying (Bjork, 1975), yielding pedagogical benefits in classroom settings (e.g., Agarwal et al., 2014; Pan, Cooke, et al., 2019) and across a wide range of materials (i.e., the testing effect; for reviews, see Pan \& Rickard, 2018; Roediger \& Karpicke, 2006b; Rowland, 2014), including spelling (e.g., Beseler, 1953; Christine \& Hollingsworth, 1966; Cook, 1957; Cohen, 1969; Jones et al., 2015; Louis, 1950; Pan et al., 2015; Schoephoerster, 1962). Thus, in recommending practice testing, the Speller incorporated a second learning technique that is now widely regarded as highly potent (Dunlosky et al., 2013; Pashler et al., 2007). Later spelling researchers have also endorsed similar testing procedures, including the self-corrected test and study-copy-cover-compare methods (e.g., Allred, 1966; Fitzgerald, 1951; Gentry, 2004; Gilstrap, 1962; Mazzio, 1987; Reed, 2012; Wallace, 2006; Westerman, 1971).

Overall, the Speller exemplified an approach to explicit spelling instruction that reflected early $20^{\text {th }}$ century educators' belief in the central importance of spelling skills and required students to invest time on the subject on a daily basis. It was remarkably prescient in its use of two learning techniques (distributed practice and retrieval practice) that are now regarded as evidence-based and highly robust. However, as described next, other aspects of the Speller have since come under heavy criticism, and as a consequence, the textbook is now generally considered to be obsolete.

\section{Contemporary Criticisms of the Speller and Other Traditional Approaches}

The Speller's curriculum was largely rooted in behaviorist principles and perspectives, much of which are now commonly regarded as outdated (Hodges, 1982). For instance, the Speller's first author had argued that the acquisition of spelling skills should be regarded as a visual learning task (E. Horn, 1919), which was in alignment with common perspectives at the time (e.g., Gates \& Chase, 1926). Although contemporary researchers still recognize that there 
are visual components to spelling skills, non-visual components have since been established to be involved as well (Gentry, 2004; Rayner, 2001; Zesiger \& de Partz, 1997). Accordingly, the Speller's heavy reliance on visualization exercises, which reflected a goal of engaging students in repeated "drill periods" to impress words in memory, was based on an incomplete view of the cognitive mechanisms that spelling engages.

In addition, the Speller's authors did not anticipate many other research-supported techniques that have since gained wide acceptance. E. Horn $(1919,1954)$ had criticized the study of spelling rules and letter patterns as ineffective due to the apparent irregularity of English spelling, plus dismissed the utility of phonics instruction on the basis of inadequate evidence. Hence, the Speller included no such activities. Yet many spelling researchers now endorse the study of spelling rules, letter patterns, and phonics given empirical research that such activities are beneficial (e.g., Gentry, 2007; Joshi et al., 2008; Reed, 2012; Treiman, 2018). Moreover, the Speller did not include age-specific or grade-level spelling skill benchmarks (e.g., successful use of consonant doubling). The absence of such benchmarks is unsurprising given that most research on the developmental progression of spelling ability — which led to stage models of spelling by Gentry (1982), Henderson (1985), Ehri (1986), Bear and Templeton (1998), and others-had not yet occurred. Consequently, the Speller did not allow for diagnosing individual students' spelling skills in any systematic way, such as via categorization of the types of errors committed. Rather, progression of spelling ability was simply reflected in terms of "easier" versus "more difficult" words, with levels of difficulty established via frequency counts of errors from an analysis of letters of correspondence that the Speller's authors had conducted (it should however be noted that the use of difficulty-graded lists represents an improvement over more arbitrary lists, which is a practice that persists even today in some schools).

Two staples of the Speller's curriculum, namely weekly spelling lists and the Friday 
spelling test, remain popular today. Fresch (2007) surveyed U.S. elementary school teachers and found that $84 \%$ assign their students to learn a different word list each week in preparation for a posttest (for additional survey data see Graham et al., 2008; McNeill \& Kirk, 2014). Yet it appears that many teachers no longer emphasize distributed practice or practice testing. Rather, students are commonly told to study each word list on their own in preparation for a single, endof-week posttest (Simonsen \& Gunter, 2001), after which the words are no longer revisited. In place of practice testing, non-testing activities such as consulting dictionaries or playing games occur (Fresch, 2007; Graham et al., 2008). Kilzer (1926) and other researchers have described that approach — wherein spelling is learned through the study of assigned lists and no testing occurs outside of a final posttest—as the study-test method. Although Sherwin (1969) and others have long suggested (based on empirical data) that the study-test method is inadequate relative to methods that involve practice testing, it remains popular. That popularity appears to stem from ease-of-implementation: At a bare minimum, all the instructor has to do is assign a list on Monday and proctor a test on Friday, with students otherwise left to learn via their own devices. In a potentially worrisome development, dissatisfaction with traditional approaches to spelling instruction appears to have been growing among teachers, at least anecdotally, since the 1970s. Chief among such complaints has been the observation that the weekly list-test format appears to yield rapid forgetting and poor transfer of learning. The phrase "Friday test, Monday miss" (Putman, 2017; see also Gill \& Scharer, 1996)—wherein students study sufficiently to pass a Friday test, but then appear to have forgotten what they have learned as evidenced by misspellings in later writing activities — encapsulates that phenomenon. It should be emphasized however that forgetting is ubiquituous throughout many forms of learning and can occur regardless of the training task (and as emphasized in prominent memory theories, including Bjork and Bjork's (1992) New Theory of Disuse, learning can be retained but appear to be 
inaccessible, if only temporarily). Further, some tasks have been shown to not only boost learning relative to other study activities, but also reduce the rate of forgetting (as in the case of retrieval practice; see Carpenter et al., 2008; Roediger \& Karpicke, 2006a). Other complaints target explicit instruction (e.g., the aforementioned claim that the explicit approach results in learning that is too disconnected from reading and writing activities).

Psycholinguists have also faulted traditional approaches to spelling instruction as ineffective at yielding transferrable spelling skills and fostering motivation to spell. For instance, Zutell (1978, p. 848) opined that the weekly spelling list-test format provides "little opportunity for conceptualization," constitutes "rote memorization," and ultimately yields "boredom or frustration" and "a lack of carryover from memorizing the words to using them in written products." Although such complaints most directly reflect the study-test method and not the Speller's more intensive curriculum — and appear to partly stem from a combination of opinions on teaching philosophy and anecdotal evidence — the apparent result of these and other complaints has been, over the past several decades, a growing interest in replacing traditional approaches to spelling instruction with updated versions.

\section{Alternative Perspectives on Effective Spelling Instruction}

In contrast with the perspectives held by the authors of the Speller and many others of the same era, many contemporary spelling researchers do not believe that the relative difficulty of English spelling compared to other alphabetic languages necessitates "word-by-word memorization." Supporting evidence for that belief comes from studies showing that most English words have more predictable spellings than previously assumed. In particular, Hanna et al. (1966; see also Hanna \& Moore, 1951; Kessler \& Treiman, 2003; Kreiner, 2002; Ziegler et al., 1997) conducted a series of computer analyses of over 17,000 English words and found that approximately half could be spelled using simple sound-letter combinations (i.e., phonics), over 
one-third were regular except for one sound, and most of the remainder could be derived using etymological information (e.g., having a prefix of Greek origin). After those considerations had been accounted for, only 4\% of English spellings could be regarded as unpredictable (Joshi et al., 2008). That finding led to suggestions that spelling instruction should concentrate on the regularities of English spelling (e.g., Bowers \& Bowers, 2017; Moats, 2005/2006; Treiman, 2018), or at least that spelling curricula should be modified to include some instruction on those regularities (e.g., Gentry \& Graham, 2010). Such instruction might take many different forms. For instance, Joshi et al. (2008) suggested that spelling instruction should focus on the study of (a) syllable patterns (i.e., open and closed syllables and rules governing their use), (b) morphemes (e.g., prefixes, suffixes, and roots), (c) letter patterns (i.e., rules governing the use of certain letter combinations, such as the letter $q$ always being followed by the letter $u$ ), and especially for older elementary school students, (d) etymology (including words of Greek, Latin, and French origin). Other researchers (e.g., Adoniou, 2014; Leipzig, 2000; Moats 2005/2006; Treiman \& Kessler, 2014) have proposed similar curricula and offered recommendations for effective spelling instruction, including the mixing of explicit and incidental approaches, motivating students to engage in concentrated effort when practicing spelling, and providing students with feedback.

Contemporary researchers have also adopted more expansive and detailed definitions of spelling skills. Specifically, spelling skills no longer simply entail the ability to spell correctly; rather, such skills now include phonological knowledge (i.e., phonemics and phonics), morphological knowledge (e.g., prefixes and suffixes), orthographic knowledge (e.g., phonemegrapheme relationships), etymological knowledge (i.e., word origins), and visual knowledge (e.g., how letter patterns appear to the eye), many or all of which may develop in stages (Adoniou, 2014; Bear \& Templeton, 1998; Gentry, 1982; and Henderson, 1981; for detailed 
discussion of the development of alphabetic knowledge and spelling ability, see Treiman \& Kessler, 2014). Further, the ability to use a dictionary to check the spellings of words (Graham, 1985; Hillerich, 1977), use spellcheck programs (Montgomery et al., 2001), spell unfamiliar words, and learn the spellings of unfamiliar words found in written text also constitute important spelling skills. In tandem with those definitional changes, the number of ways to learn spelling has also grown (Johnston, 2000; Schagal, 2002) and now includes a wide range of commercial spelling programs, spelling textbooks, and a variety of ad-hoc techniques invented by teachers and others.

From a contemporary perspective, explicit spelling instruction might involve any of at least three different but non-exclusive approaches, each of which might be implemented in diverse ways (Reed, 2012; Simonsen \& Gunter, 2001). As shown in Table 4, the most common include the (a) phonemic and (b) morphemic approaches, which focus on the regularities of English spelling (as emphasized by many contemporary spelling researchers), as well as other instructional techniques, such as self-corrected tests, that can be classified under the (c) whole word approach. The phonemic approach focuses on meaningful units of sound and sound-letter correspondences, an example of which involves the study of phonics rules. The morphemic approach involves learning about units of letters that carry meaning, an example of which is the study of morphological rules. The whole word approach involves memorizing the spellings of entire words and especially those that are irregular by at least one sound (Reed, 2012). Under that approach (which should not be confused with the "whole language" approach that promotes incidental learning of literacy skills via immersion in reading and writing activities; e.g., Altwerger et al., 1987), words are not divided into segments and are instead learned in their entirety (e.g., O'Connor \& Padeliadu, 2000), such as via self-corrected tests. It should be emphasized that the three approaches summarized here do not necessarily encompass the entirety 
of contemporary methods of explicit spelling instruction, but rather exemplify widely-used methods that many researchers currently endorse. These approaches also represent a marked contrast from the methods espoused in the Speller a century ago, including with respect to the use of distributed practice and retrieval practice.

\section{Research-Supported and Unsupported Instructional Approaches}

In the spelling literature, some common implementations of the phonemic, morphemic, and whole word approaches have received empirical support. For instance, a series of metaanalyses involving experimental and quasi-experimental studies have concluded that both the phonemic approach (in the form of phonemic awareness instruction as analyzed by Ehri et al., 2001, 2003) and the morphemic approach (via instructional methods that included an emphasis on morphemes as units of meaning, as analyzed by Goodwin \& Ahn, 2013; see also Carlisle, 2010) can improve spelling skills. Qualitative reviews of at least one implementation of the whole word approach, namely the self-corrected test, have also concluded in favor of its effectiveness (e.g., Simonsen \& Gunter, 2001). However, the meta-analytic literature on spelling (and reading) instruction may not be as conclusive as has long been believed: Bowers (2020) reviewed 12 meta-analyses purporting to support the effectiveness of systematic phonics instruction for reading skills (and, where documented, spelling skills; e.g., Ehri et al., 2001) and identified flaws in data collection and analysis, including inconsistencies in the implementation of instruction across included studies, comparisons involving heterogenous control conditions, mixing of different outcome measures, inconsistent and unexpectedly high variability in effect sizes across studies, and potential publication bias. These criticisms pose a challenge for the spelling and reading instruction literature as a whole and imply that the efficacy of common implementations of the phonemic, morphemic, and whole word approaches remains to be fully established, despite favorable indications in some peer-reviewed research. 
Further complicating matters, other instructional techniques that do not enjoy any evidentiary support have also emerged in recent years. These techniques are often presented in user-friendly lists of activities to attempt. For instance, a list of 18 "creative and interactive" spelling activities recently published by the commercial education website ThoughtCo features such tasks as playing hangman, using spelling words to make a fly swatter, and play-acting spelling words (Morin, 2020). Although evidently well-intended, these activities do not directly address any of the aforementioned spelling skills or involve any of the research-supported approaches described above. Rather, such activities appear to have simply been designed to be enjoyable and to expose learners to the letters in words. Although some spelling researchers have endorsed games and other fun activities as a way of promoting interest in spelling, those researchers have often emphasized that such activities are only meant to supplement other forms of instruction (e.g., E. Horn, 1954; Graham, 1983), a crucial point that many lists omit. Further, references to the "learning styles" myth (i.e., that instruction should be tailored toward students' preferred mode of learning, such as visual, auditory, or kinesthetic), along with advice to choose activities accordingly, are often included in such lists. Despite popular acceptance of the learning styles myth (for survey data, see Dekker et al., 2012), there are no reliable benefits to arranging instruction according to learning styles (Pashler et al., 2009; see also Coffield et al., 2004; Cuevas, 2015; Coffield et al., 2004, Willingham et al., 2015).

The existence and use of instructional techniques of dubious pedagogical value is not a new phenomenon in the spelling literature. Rice (1897), Cohen (1969), Graves (1977), Fitzsimmons and Loomer (1977), Graham (1980), Cronnell and Humes (1980), and Mazzio (1987) have commented on the disparity between research-supported and common practices. However, the emergence of vastly different approaches to spelling instruction-a trend that generally coincides with growing dissatisfaction with and decline in the use of traditional 
methods - appears to have led to an unprecedented proliferation of such techniques. Indeed, a Google search conducted for this article using the keyword "spelling activities" yielded well over 1.8 million hits, and a partial review of the results revealed that only a portion of those hits involve activities that are grounded in research. Accordingly, when deciding on the manner and method of teaching spelling, today's instructors would be well-advised to take great care to identify and use research-supported methods, which is admittedly challenging given the plethora of available instructional methods and different levels of evidence regarding the efficacy of each.

\section{Reconsidering the Role of Spelling Tests}

Of all the elements that have been common to traditional forms of spelling instruction, spelling tests have been the most directly targeted for extinction in recent years. For instance, of the approximately 250 schools mentioned at the outset of this article, all have eliminated (or been directed to eliminate) spelling tests. The removal of spelling tests has been justified by claims that such tests are useless for learning, uninformative, only reflect "short-term memory," promote memorization at the expense of transfer, are too stressful or unenjoyable for students, and constitute inauthentic assessments of spelling ability (e.g., Adoniou, 2013; BBC News, 2008; Carreker, 2010; Cheek, 2011; Murray, 2015; Putman, 2017). Although spelling tests still remain dominant-well over three-quarters of primary school teachers report using them (e.g., Fresch, 2007; McNeill \& Kirk, 2014)—that trend raises the question: Do tests still deserve a place in spelling instruction? A closer examination of relevant issues and evidence is warranted.

In media reports and other pronouncements regarding the elimination of spelling tests, distinctions between different types of tests are usually unmentioned. Rather, all such tests appear to have been removed indiscriminately. However, despite the stereotypical image of a test as that of a dreaded high-stakes exam, tests can be low-stakes or high-stakes and used for assessment or pedagogical purposes (for reviews, see Roediger \& Karpicke, 2006b; Roediger \& 
Butler, 2011). Further, tests can be administered in a variety of formats and taken at different points in the learning process (Benjamin \& Pashler, 2015; Pan \& Sana, 2021). Three test types are particularly relevant for spelling instruction: (a) pretests, (b) practice tests, and (c) posttests. Each type has specific purposes, at least one of which is unique.

In spelling instruction, the pretest-that is, a typically low-stakes test that occurs before any substantial learning activities have taken place-is intended to measure what students do and do not already know. Such tests may simply involve students attempting to spell words that are dictated aloud, whereas with other implementations, such as a spelling inventory (e.g., Johnston, 1997), students' spelling skills may be assessed according to developmental stage benchmarks. Pretests commonly enable instructors to focus instructional time on content that students have yet to master, as opposed to content that has already been learned. For instance, if a pretest reveals that a student has sufficient mastery of certain morphological rules and not others, then an instructor might engage that student in activities involving the rules that have yet to be learned. In the spelling literature, that "concentrated attack" (Horn \& Ashbaugh, 1920, p. viii) on difficult words or materials is thought to be highly beneficial. In fact, Allred (1984) and others have attributed the superiority of the test-study-test method (in which a pretest is followed by other learning activities that lead to a posttest) over the study-test method (e.g., Gates, 1931; Fitzgerald, 1953; Kilzer, 1926; Sherwin, 1969) to the diagnostic information that pretests provide. Overall, the consensus among many spelling researchers is that pretests yield useful and often critically important information (Gentry, 2007; Graham, 1983; Harris et al., 2017), contrary to claims that spelling tests are uninformative.

Another potential benefit of pretesting involves its capacity to enhance learning itself. Recent research has demonstrated the pretesting or prequestion effect (e.g. Kornell et al., 2009; Pan et al., 2019), in which learners exhibit improved memory for information that is encountered 
on a pretest, relative to information that is simply studied and not pretested. These studies suggest that taking a pretest can lead to enhanced processing of the correct answers, and possibly because such guessing increases interest in the answers (Kornell \& Vaughn, 2016; Pan et al., 2020). The opportunity to study the correct answers after a pretest is a precondition for learning benefits to manifest (Treiman \& Kessler, 2014). However, pretesting has not yet been applied to spelling in controlled experiments. Hence, whereas the diagnostic capabilities of pretests for spelling are well-established, the extent to which pretests improve spelling ability directly remains to be investigated.

In spelling curricula, a practice test-that is, low-stakes tests wherein learners engage in retrieval practice after having had an opportunity to study—is intended to enhance (as opposed to measure) learning. As noted earlier, a large body of literature has shown that taking practice tests yields substantial pedagogical benefits (Bjork, 1975), including enhanced memory and retention, in some cases, better transfer of learning (Carpenter, 2012; Pan \& Agarwal, 2018; Pan \& Rickard, 2018). Providing correct answer feedback shortly after the test enhances its benefits (Rowland, 2014). A host of spelling researchers, including T. D. Horn (1947), Cook (1957), and Cohen (1969), have shown that practice testing in the form of the self-corrected test and/or the study-copy-cover-compare method yields better memory for the spellings of words than alternative tasks such as segmenting words, studying meanings of words, supplying missing letters, and other methods. Accordingly, many contemporary spelling researchers strongly recommend practice testing as an effective way to learn spelling words (e.g., Harris et al., 2017; Gentry, 2011; Graham et al., 2008; Reed, 2012). Practice testing may be the most helpful for words that are irregular for at least one sound, given that rules or other regularities are not fully adequate to guide correct spelling in those cases. It should also be noted that despite complaints about the stressful nature of spelling tests (though more applicable to high-stakes exams), low- 
stakes practice tests have been shown to reduce test anxiety rather than exacerbate it (e.g., Agarwal et al., 2014).

Two recent studies provide further insights into the value of practice testing. Across three experiments conducted in U.S. classrooms, Jones et al. (2015) had $1^{\text {st }}$ and $2^{\text {nd }}$ grade students first take a pretest and then learn spelling words using self-corrected tests or a method known as rainbow writing. Often appearing on lists of "fun" spelling activities, rainbow writing entails copying words multiple times in different colors. In each experiment, practice testing yielded better ability to spell words on a posttest that occurred one day and/or five weeks later. Among $1^{\text {st }}$ grade students, the magnitude of pretest-to-posttest improvement from practice testing exceeded that from rainbow writing by over $300 \%$. Additionally, students consistently reported liking testing more than rainbow writing by an approximately three-to-one margin. These results counter the claim that testing only reflects "short-term memory" (when benefits were observed at extended time intervals, as has occurred in prior work) and refute the suggestion that testing is unenjoyable. One possible explanation for students' preference for practice testing is that the experience of improving across successive tests is intrinsically motivating (for related theorizing see E. Horn \& Ashbaugh, 1920). In contrast, rainbow writing did not yield consistent improvements. Overall, the results of Jones et al. reinforce the conclusion that practice testing can be a potent method of spelling instruction.

Possible limitations of practice testing are however suggested by Dymock and Nicholson (2017). In their study, $3^{\text {rd }}$ grade students in a New Zealand elementary school learned spelling words across a ten-week period in one of two groups. The "list" group engaged in alphabetizing words, writing them in sentences, and using the study-copy-cover-compare method (i.e., practice testing), whereas the "strategy" group learned spelling rules (e.g., consonant doubling), practiced breaking words into syllables, and learned to identify vowel sounds. On weekly posttests, both 
groups performed equivalently when asked to spell the words that they had already learned, but the strategy group performed better when asked to spell new words that conformed to the rules that they had previously learned. Although the multi-task design and arguably inequitable access to information during training complicates interpretation (i.e., the strategy group had direct access to additional content), Dymock and Nicholson's results lend credence to the criticism that spelling tests support memorization more than transfer (see also Arra \& Aaron, 2001). It should be noted, however, that the use of practice tests to learn spelling rules rather than just specific words, which has not been investigated to date, may have yielded more transferrable learning. Further, in the broader retrieval practice literature, swapping relatively low order practice test formats (e.g., simple cued recall) with higher order formats (e.g., requiring the generation of explanations) and tests with more detailed feedback can yield substantially more transfer (e.g., Hinze et al., 2011; see also Agarwal, 2019, Pan, Hutter, et al., 2019), but such tests have also not been investigated in the spelling literature to date.

Finally, the posttest (also called a criterial test or final test) is used in spelling instruction to assess the outcome of instructional activities. As Gentry (2011) and others have observed (e.g., Dunn, 2019), posttests hold instruction accountable. Without such tests, it is difficult to identify the aspects of spelling skills that students have successfully mastered or not. Posttests may take the form of the traditional Friday spelling test wherein the ability to spell words from an assigned list is assessed (such a test has face validity given that it involves retrieval of a word's spelling from memory, much as students do during writing). However, critics of traditional approaches to spelling, such as Hilden and Jones (2012), suggest that posttests should instead assess different components of spelling skills, such as knowledge of specific word features. In either case, posttests are often highly informative as to the state of students' spelling abilities. An alternative to posttesting involves analyzing students' writing in their essays and 
homework; such analyses are arguably the most authentic at measuring spelling ability, but can be more time-consuming and may miss benchmarks that posttests directly target (it should be noted, however, that scoring posttests can also take considerable amounts of time, and particularly when students' handwriting is poor). Overall, a consensus among many spelling researchers is that posttests are useful to help determine the efficacy of any spelling curricula that is being implemented (Gentry, 2011; Wallace, 2006; Westwood, 2014; see also Allred, 1984)— be it explicit or incidental, phonemic or morphemic, or otherwise.

\section{Concluding Remarks}

A wealth of spelling research provides answers to the questions posed at the outset of this article. First, in the $21^{\text {st }}$ century, spelling does still matter. In fact, in many respects-from the employment sector to perceptions of writers and their writing, and even in online settingsspelling matters at least as much as it has in prior centuries. Second, there is substantial evidence favoring the explicit teaching of spelling. Although the accrual of spelling ability follows a developmental trajectory, and human beings have some capacity for developing spelling proficiency on their own, it is unrealistic to assume that spelling abilities will develop fully in the absence of explicit instruction. Third, some aspects of traditional spelling curricula, such as the use of spelling tests popularized by the Horn-Ashbaugh Speller and other textbooks of the same era, remain valid today, whereas others, such as an exclusive focus on learning individual words rather than patterns common to multiple words, are not.

Importantly, although there are many irregularities in English spelling, the study of the regularities that do exist, which was once derided as ineffective and unimportant, is now recommended by many spelling researchers. Such study might occur via phonemic, morphemic, and other instructional approaches, of which some instantiations enjoy at least some empirical support. Moreover, although the ability to spell is now considered to involve multiple skills 
ranging from knowledge of spelling patterns to spelling unfamiliar words, the potential exists, based on our examination of the spelling literature, to design curricula that help develop students' proficiency in all of those constituent skills.

The English language's Anglo-Saxon roots, as modified by the influence of other languages, such as Greek, Latin, and French, have led to a language that is efficient by some measures, such as number of words needed to express a request or issue a warning, and which is characterized by competing spelling rules and frequent mismatches between spelling and pronounciation. From an efficiency standpoint, children learning English as a first language and adults learning English as a second language might wish that were not the case, but for a variety of reasons it is unrealistic to think that some government intervention will redo the English language in a way that aligns spelling and pronounciation to the same degree as other alphabetic languages. Noah Webster, in 1806, in his A Compendious Dictionary of the English Language, had the stature to eliminate some inconsistencies in English spelling, which led to some small changes, such as dropping the "u" in color and and honor and the final "k" in words such as public and music, but it is difficult to imagine any large scale changes happening in this era. If correct spelling remains important for all of the reasons we have stressed, then our basic message is that we need to draw on what we know across multiple psychological disciplines to optimize the learning process - that is, taking advantage of research-supported tools and approaches where available, including explicit spelling instruction, practice testing, and psycholinguistic approaches. Also, activities that reflect societal approbiation of the importance of spelling, such as the long tradition of spelling bee competitions, which have been uniquely popular in the U.S., should be encouraged.

Finally, it should be emphasized that there remains substantially more to be learned about the development and bases of spelling skills and how to optimize spelling instruction. In 
particular, the plethora of instructional techniques now in existence deserve to be subjected to well-controlled and well-powered experimental studies that support strong causal inference (in a literature that has arguably relied too heavily on small- $n$ studies). More rigorous research designs are needed to provide more definitive evidence, and alternative instructional methods need to be scrutinzed. New systematic reviews and meta-analyses of instructional techniques should attempt to avoid the methodological and interpretative limitations that have affected prior such efforts. Last but not least, further research to identify any influences of technological innovations on spelling is definitely warranted. In short, there is still more to understand about spelling, which Noah Webster once described as "the foundation of reading and the greatest ornament of writing" (Webster, 1783, p. 26), and which an abundance of evidence indicates remains fundamentally important in modern society. 


\section{References}

Abbott, R. D., Berninger, V. W., \& Fayol, M. (2010). Longitudinal relationships of levels of language in writing and between writing and reading in grades 1 to 7 . Journal of Educational Psychology, 102(2), 281-298. https://doi.org/10.1037/a0019318

Adecco. (2013, May 9). Hiring Managers Believe New College Grads are Unprepared for the Workforce.

https://web.archive.org/web/20170131043335/https://www.adeccousa.com/about-adeccostaffing/newsroom/press-releases/college-grads-unprepared-for-workforce-2013/

Adoniou, M. (2013, November 24). Why some kids can't spell and why spelling tests won't help. The Conversation. http://theconversation.com/why-some-kids-cant-spell-and-whyspelling-tests-wont-help-20497

Adoniou, M. (2014). What should teachers know about spelling? Literacy, 48(3), 144-154. https://doi.org/10.1111/lit.12017

Agarwal, P. K., D’Antonio, L., Roediger, H. L., McDermott, K. B., \& McDaniel, M. A. (2014). Classroom-based programs of retrieval practice reduce middle school and high school students' test anxiety. Journal of Applied Research in Memory and Cognition, 3(3), 131139. https://doi.org/10.1016/j.jarmac.2014.07.002

Allred, R. A. (1966). Application of spelling research. Curriculum Bulletin, 22(268), 1-26.

Allred, R. A. (1977). Spelling: The application of research findings. National Education Association. https://eric.ed.gov/?id=ED135003

Allred, R. A. (1984). Spelling trends, content, and methods. What research says to the teachers. National Education Association. https://eric.ed.gov/?id=ED248531

Altwerger, B., Edelsky, C., \& Flores, B. M. (1987). Whole language: What's new? The Reading Teacher, 41(2), 144-154. 
Arizona State University. (2020). Netiquette for online students.

https://asuonline.asu.edu/newsroom/online-learning-tips/netiquette-online-students/

Arra, C. T., \& Aaron, P. G. (2001). Effects of psycholinguistic instruction on spelling performance. Psychology in the Schools, 38(4), 357-363. https://doi.org/10.1002/pits.1024

Bahrick, H. P., Bahrick, L. E., Bahrick, A. S., \& Bahrick, P. E. (1993). Maintenance of Foreign Language Vocabulary and the Spacing Effect. Psychological Science, 4(5), 316-321. https://doi.org/10.1111/j.1467-9280.1993.tb00571.x

Barker, O., \& Puente, M. (2013, August 5). Does spelling still matter? https://www.usatoday.com/story/life/people/2013/08/05/does-spelling-still-countjeopardy-thomas-hurley-boy/2619957/

BBC News. Pupils “distressed over spelling.” (2008, October 2). http://news.bbc.co.uk/2/hi/uk_news/england/gloucestershire/7648274.stm

Bear, D. R., \& Templeton, S. (1998). Explorations in developmental spelling: Foundations for learning and teaching phonics, spelling, and vocabulary. 21.

Benjamin, A. S., \& Pashler, H. (2015). The value of standardized testing: A perspective from cognitive psychology. Policy Insights from the Behavioral and Brain Sciences, 2(1), 1323. https://doi.org/10.1177/2372732215601116

Berninger, V. W., Vaughan, K., Abbott, R. D., Begay, K., Coleman, K. B., Curtin, G., Hawkins, J. M., \& Graham, S. (2002). Teaching spelling and composition alone and together: Implications for the simple view of writing. Journal of Educational Psychology, 94(2), 291-304. https://doi.org/10.1037/0022-0663.94.2.291

Beseler, D. (1953). An experiment in spelling using the corrected test method. Central Washington University. https://digitalcommons.cwu.edu/etd/90 
Bestler, L. (2015). Netiquette at ISU. https://www.celt.iastate.edu/wpcontent/uploads/2015/09/netiquetteatISU.pdf

Bjork, R. A. (1975). Retrieval as a memory modifier: An interpretation of negative recency and related phenomena. In R.L. Solso (Ed.), Information processing and cognition: The Loyola Symposium (pp. 123-144). Erlbaum.

Bjork, R. A., \& Bjork, E. L. (1992). A new theory of disuse and an old theory of stimulus fluctuation. In Essays in honor of William K. Estes, Vol. 1: From learning theory to connectionist theory; Vol. 2: From learning processes to cognitive processes (pp. 35-67). Lawrence Erlbaum Associates, Inc.

Bosman, A. M. T., \& Van Orden, G. C. (1997). Why spelling is more difficult than reading. In C. A. Perfetti, L. Rieben, \& M. Fayol (Eds.), Learning to spell: Research, theory, and practice across languages (p. 173-194). Lawrence Erlbaum Associates Publishers.

Bowers, J. S. (2020). Reconsidering the evidence that systematic phonics is more effective than alternative methods of reading instruction. Educational Psychology Review, 1-25.

Bowers, J. S., \& Bowers, P. N. (2017). Beyond phonics: The case for teaching children the logic of the english spelling system. Educational Psychologist, 52(2), 124-141. https://doi.org/10.1080/00461520.2017.1288571

California Department of Education. (1998). Star State Summary Report. https://star.cde.ca.gov/star98/reports/00-00000-0000000.html

California Department of Education. (1999). Star State Summary Report. https://star.cde.ca.gov/star99/reports/19/English.html

California Department of Education. (2000). Star State Summary Report. https://star.cde.ca.gov/star2000f/reports/01.html 
California Department of Education. (2001). Star State Summary Report. https://star.cde.ca.gov/star2001/report.asp?CDSCode=00000000000000000000\&CL=1

California Department of Education. (2002). Star State Summary Report. https://web.archive.org/web/20180406175648/https://star.cde.ca.gov/star2002/report.asp? CDSCode $=00000000000000000000 \& C L=1$

Carlisle, J. F. (2010). Effects of instruction in morphological awareness on literacy achievement: An integrative review. Reading Research Quarterly, 45(4), 464-487. https://doi.org/10.1598/RRQ.45.4.5

Carpenter, S. K. (2012). Testing enhances the transfer of learning. Current Directions in Psychological Science, 21(5), 279-283. https://doi.org/10.1177/0963721412452728

Carpenter, S. K., Pashler, H., Wixted, J. T., \& Vul, E. (2008). The effects of tests on learning and forgetting. Memory \& Cognition, 36(2), 438-448.

Carreker, S. (2020, January 6). Memorization wrong path to proficiency in spelling [Editorial]. Houston Chronicle. https://www.chron.com/opinion/outlook/article/Memorizationwrong-path-to-proficiency-in-spelling-1707582.php

Cepeda, N. J., Pashler, H., Vul, E., Wixted, J. T., \& Rohrer, D. (2006). Distributed practice in verbal recall tasks: A review and quantitative synthesis. Psychological Bulletin, 132(3), 354-380. https://doi.org/10.1037/0033-2909.132.3.354

Cheek, L. (2016, June 15). Yes! We do teaching spelling! Oldham County Schools. https://web.archive.org/web/20160615160234/https://www.oldham.kyschools.us/buckner /images/stories/DocumentsForms/Newsletters/Spelling_Article_2011.pdf

Chomsky, C. (1971). Invented spelling in the open classroom. WORD, 27(1-3), 499-518. https://doi.org/10.1080/00437956.1971.11435643 
Christensen, D. S., \& Rees, D. (2002). An analysis of the business communication skills needed by entry-level accountants. Mountain Plains Journal of Business and Economics, 3, 15.

Christine, R., \& Hollingsworth, P. (1966). An experiment in spelling. Education, 86, 565-567.

Coffield, F., Moseley, D., Hall, E., \& Ecclestone, K. (2004). Should we be using learning styles?: What research has to say to practice. National Centre for Vocational Education Research. https://www.voced.edu.au/content/ngv:12401\#

Cohen, L. A. (1969). Evaluating Structural Analysis Methods Used in Spelling Books. University Microfilms, A Xerox Company, 300 North Zeeb Rd.

Colvin, R. L. (1995, September 13). State report urges return to basics in teaching reading. Los Angeles Times. https://www.latimes.com/archives/la-xpm-1995-09-13-mn-45333story.html

Connors, R. J., \& Lunsford, A. A. (1988). Frequency of formal errors in current college writing, or Ma and Pa Kettle Do Research. College Composition and Communication, 39(4), 395409. https://doi.org/10.2307/357695

Consumer Reports (October 2012). How to not get phished. https://www.consumerreports.org/cro/2012/10/how-to-not-get-phished/index.htm

Constantinou, F., \& Chambers, L. (2020). Non-standard English in UK students' writing over time. Language and Education, 34(1), 22-35.

Constantinou, F., Chambers, L., Zanini, N., \& Klir, N. (2020). A diachronic perspective on formality in students' writing: Empirical findings from the UK. Language, Culture and Curriculum, 33(1), 66-83.

Cook, R. C. (1957). Evaluation of two methods of teaching spelling. The Elementary School Journal, 58(1), 21-27. https://doi.org/10.1086/459590 
Cooper, A. E., Diab, D. L., \& Beeson, K. M. (2020). Why spelling errors matter: Online company reviews and organizational attraction. Corporate Reputation Review, 23(3), 160-169. https://doi.org/10.1057/s41299-019-00075-z

Coote, E. (1596). The English Schoole-Maister: Teaching all his schollers, the order of distinct reading, and true writing our English tongue. Ralph Jackson \& Robert Dexter.

Coughlan, S. (2011, July 14). Spelling mistakes "cost millions" in lost online sales-BBC News. BBC News. https://www.bbc.com/news/education-14130854

Cronnell, B., \& Humes, A. (1980). Elementary spelling: What's really taught. The Elementary School Journal, 81(1), 59-64. https://doi.org/10.1086/461208

Cuevas, J. (2015). Is learning styles-based instruction effective? A comprehensive analysis of recent research on learning styles. Theory and Research in Education, 13(3), 308-333. https://doi.org/10.1177/1477878515606621

Dekker, S., Lee, N. C., Howard-Jones, P., \& Jolles, J. (2012). Neuromyths in Education: Prevalence and Predictors of Misconceptions among Teachers. Frontiers in Psychology, 3. https://doi.org/10.3389/fpsyg.2012.00429

Denn, R. (2019, January 29). In the era of spellcheck and auto-correct, does it matter that my son can't spell? Washington Post. https:/www.washingtonpost.com/lifestyle/2019/01/29/eraspellcheck-autocorrect-does-it-matter-that-my-son-cant-spell/

Department of Education. (2013, May 14). New grammar, punctuation and spelling test will raise children's literacy standards. Gov.Uk. https://www.gov.uk/government/news/newgrammar-punctuation-and-spelling-test-will-raise-childrens-literacy-standards

Dewar, C. (2017, May 4). Changes to the teaching of spelling. Holme Community School. https://www.holmeschool.cumbria.sch.uk/news/detail/changes-to-the-teaching-ofspelling/ 
Drouin, M. A. (2011). College students' text messaging, use of textese and literacy skills. Journal of Computer Assisted Learning, 27(1), 67-75. https://doi.org/10.1111/j.13652729.2010.00399.x

Drouin, M., \& Davis, C. (2009). R u txting? Is the use of text speak hurting your literacy? Journal of Literacy Research, 41(1), 46-67. https://doi.org/10.1080/10862960802695131

Dunlosky, J., Rawson, K. A., Marsh, E. J., Nathan, M. J., \& Willingham, D. T. (2013). Improving students' learning with effective learning techniques: Promising directions from cognitive and educational psychology. Psychological Science in the Public Interest, 14(1), 4-58. https://doi.org/10.1177/1529100612453266

Dymock, S., \& Nicholson, T. (2017). To what extent does children's spelling improve as a result of learning words with the look, say, cover, write, check, fix strategy compared with phonological spelling strategies? Australian Journal of Learning Difficulties, 22(2), 171187. https://doi.org/10.1080/19404158.2017.1398766

Ebbinghaus, H. (1885). Über das Gedächtnis: Untersuchungen zur experimentellen Psychologie. Duncker \& Humblot.

Edelsky, C. (1990). Whose agenda is this anyway? A response to McKenna, Robinson, and Miller. Educational Researcher, 19(8), 7-11. https://doi.org/10.3102/0013189X019008007

Ehri, L. C. (1986). Sources of difficulty in learning to spell and read. Advances in Developmental \& Behavioral Pediatrics, 7, 121-195.

Ehri, L. C. (1987). Learning to read and spell words. Journal of Reading Behavior, 19(1), 5-31. https://doi.org/10.1080/10862968709547585

Ehri, L. C. (2003). Systematic phonics instruction: Findings of the National Reading Panel. https://eric.ed.gov/?id=ED479646 
Ehri, L. C., Nunes, S. R., Willows, D. M., Schuster, B. V., Yaghoub-Zadeh, Z., \& Shanahan, T. (2001). Phonemic Awareness Instruction Helps Children Learn to Read: Evidence From the National Reading Panel's Meta-Analysis. Reading Research Quarterly, 36(3), 250_ 287. https://doi.org/10.1598/RRQ.36.3.2

Epstein, D. (2006, April 19). Be polite, e-polite. Inside Higher Ed. https://www.insidehighered.com/news/2006/04/19/be-polite-e-polite

Everard, A., \& Galletta, D. F. (2005). How Presentation Flaws Affect Perceived Site Quality, Trust, and Intention to Purchase from an Online Store. Journal of Management Information Systems, 22(3), 56-95. https://doi.org/10.2753/MIS0742-1222220303

Figueredo, L., \& Varnhagen, C. K. (2005). Didn't you run the spell checker? Effects of type of spelling error and use of a spell checker on perceptions of the author. Reading Psychology, 26(4-5), 441-458. https://doi.org/10.1080/02702710500400495

Fitzgerald, J. A. (1951). The Teaching of spelling. Bruce Publishing Company.

Fitzgerald, J. A. (1953). The Teaching of spelling. Elementary English, 30(2), 79-85.

Fitzsimmons, R. J., \& Loomer, B. M. (1977). Spelling research and practice. Iowa State Department of Public Instruction.

Flaherty, C. (2019, August 29). Professors offer advice on teaching students how to email them. Inside Higher Ed. https://www.insidehighered.com/news/2019/08/29/professors-offeradvice-teaching-students-how-email-them

Fletcher, J. M., Savage, R., \& Vaughn, S. (2020). A Commentary on Bowers (2020) and the Role of Phonics Instruction in Reading. Educational Psychology Review, 1-26.

Fresch, M. J. (2007). Teachers' concerns about spelling instruction: A national survey. Reading Psychology, 28(4), 301-330. https://doi.org/10.1080/02702710701545510 
Frith, U. (1978). Spelling difficulties. Journal of Child Psychology and Psychiatry, 19(3), 279286. https://doi.org/10.1111/j.1469-7610.1978.tb00470.x

Fry, L. (2015, September 11). Lee County Schools revamp spelling, writing courses. http://www.nbc-2.com/story/30013376/lee-county-schools-revamp-spelling-writingcourses\#.Vf883vl5c3h

Galletta, D. F., Durcikova, A., Everard, A., \& Jones, B. M. (2005). Does spell-checking software need a warning label? Communications of the ACM, 48(7), 82-86. https://doi.org/10.1145/1070838.1070841

Galuschka, K., Görgen, R., Kalmar, J., Haberstroh, S., Schmalz, X., \& Schulte-Körne, G. (2020). Effectiveness of spelling interventions for learners with dyslexia: A meta-analysis and systematic review. Educational Psychologist, 55(1), 1-20.

Gates, A. I. (1931). An experimental comparison of the study-test and test-study methods in spelling. Journal of Educational Psychology, 22(1), 1-19. https://doi.org/10.1037/h0075394

Gates, A. I., \& Chase, E. H. (1926). Methods and theories of learning to spell tested by studies of deaf children. Journal of Educational Psychology, 17(5), 289-300. https://doi.org/10.1037/h0068697

Gentry, J. R. (1982). An analysis of developmental spelling in "GNYS AT WRK." The Reading Teacher, 36(2), 192-200.

Gentry, J. R. (2004). The science of spelling: The explicit specifics that make great readers and writers (1st Edition). Heinemann.

Gentry, J. R. (2007). Spelling connections: Research and stages of spelling development. ZanerBloser. http://bpsassets.weebly.com/uploads/9/9/3/2/9932784/gentry.pdf 
Gentry, J. R. (2010, August 31). No spelling book in your child's book bag spells trouble ahead!. Psychology Today. https://www.psychologytoday.com/blog/raising-readers-writers-andspellers/201008/no-spelling-book-in-your-child-s-book-bag-spells

Gentry, J. R. (2011, March 11). A fad that fails our children: No more spelling tests! Psychology Today. https://www.psychologytoday.com/blog/raising-readers-writers-andspellers/201103/fad-fails-our-children-no-more-spelling-tests

Gentry, J. R. (2013, February 25). New standards demand higher expectations for spelling. Psychology Today. http://www.psychologytoday.com/blog/raising-readers-writers-andspellers/201302/new-standards-demand-higher-expectations-spelling

Gentry, J. R. (2017, July 13). Lousy spelling_-Why americans can't read or think well. Psychology Today. https://www.psychologytoday.com/blog/raising-readers-writers-andspellers/201707/lousy-spelling-why-americans-can-t-read-or-think

Gentry, J. R., \& Graham, S. (2010). Creating better readers and writers. Saperstein Associates. https://www.zanerbloser.com/products/pdfs/Creating_Better_Readers_and_Writers_White_Paper.pdf

Gill, C. H., \& Scharer, P. L. (1996). "Why do they get it on Friday and misspell it on Monday?" Teachers inquiring about their students as spellers. Language Arts, 73(2), 89-96.

Gilstrap, R. (1962). The development of independent spelling skills in the intermediate grades. Elementary English, 39(5), 481-485.

Glater, J. D. (2006, February 21). To: Professor@University.edu Subject: Why it's all about me. The New York Times. https://www.nytimes.com/2006/02/21/education/toprofessoruniversityedu-subject-why-its-all-about-me.html 
Goodwin, A. P., \& Ahn, S. (2010). A meta-analysis of morphological interventions: Effects on literacy achievement of children with literacy difficulties. Annals of Dyslexia, 60(2), 183208. https://doi.org/10.1007/s11881-010-0041-X

Goodwin, A. P., \& Ahn, S. (2013). A meta-analysis of morphological interventions in english: Effects on literacy outcomes for school-age children. Scientific Studies of Reading, 17(4), 257-285. https://doi.org/10.1080/10888438.2012.689791

Graham, S. (1983). Effective spelling instruction. The Elementary School Journal, 83(5), 560567. https://doi.org/10.1086/461334

Graham, S. (1985). Evaluating spelling programs and materials. TEACHING Exceptional Children, 17(4), 299-303. https://doi.org/10.1177/004005998501700410

Graham, S. (1999). Handwriting and spelling instruction for students with learning disabilities: A review. Learning Disability Quarterly, 22(2), 78-98. https://doi.org/10.2307/1511268

Graham, S. (2000). Should the natural learning approach replace spelling instruction? Journal of Educational Psychology, 92(2), 235-247.

Graham, S., Berninger, V. W., Abbott, R. D., Abbott, S. P., \& Whitaker, D. (1997). Role of mechanics in composing of elementary school students: A new methodological approach. Journal of Educational Psychology, 89(1), 170-184.

Graham, S., \& Harris, K. R. (2005). Improving the writing performance of young struggling writers: theoretical and programmatic research from the center on accelerating student learning. The Journal of Special Education, 39(1), 19-33. https://doi.org/10.1177/00224669050390010301

Graham, S., Harris, K. R., \& Chorzempa, B. F. (2002). Contribution of spelling instruction to the spelling, writing, and reading of poor spellers. Journal of Educational Psychology, 94(4), 669-686. https://doi.org/10.1037/0022-0663.94.4.669 
Graham, S., \& Hebert, M. (2010). Writing to Read. http://dl.ueb.edu.vn/handle/1247/10013

Graham, S., Morphy, P., Harris, K. R., Fink-Chorzempa, B., Saddler, B., Moran, S., \& Mason, L. (2008). Teaching spelling in the primary grades: A national survey of instructional practices and adaptations. American Educational Research Journal, 45(3), 796-825. https://doi.org/10.3102/0002831208319722

Graham, S., \& Santangelo, T. (2014). Does spelling instruction make students better spellers, readers, and writers? A meta-analytic review. Reading and Writing, 27(9), 1703-1743. https://doi.org/10.1007/s11145-014-9517-0

Graves, D. H. (1977). Research update: Spelling texts and structural analysis methods. Language Arts, 54(1), 6.

Greer, N., Teevan, J., \& Iqbal, S. (2016). An introduction to technological support for writing. ACM Conference on Human Factors in Computing Systems, 12.

Hanna, P. R., Hanna, J. S., Hodges, R. E., \& Rudorf, E. H. (1966). Phoneme-grapheme correspondences as cues to spelling improvement. U.S. Department of Health, Education, and Welfare. https://eric.ed.gov/?id=ED128835

Hanna, P. R., \& Moore, James T. (1953). Spelling-from spoken word to written symbol. The Elementary School Journal, 53(6), 329-337. https://doi.org/10.1086/458498

Harris, K. R., Graham, S., Aitken, A. A., Barkel, A., Houston, J., \& Ray, A. (2017). Teaching spelling, writing, and reading for writing: Powerful evidence-based practices. TEACHING Exceptional Children. https://doi.org/10.1177/0040059917697250

Henderson, E. H. (1985). Teaching spelling. Houghton Mifflin.

Hilden, K., \& Jones, J. (2012, July). Traditional spelling lists: Old habits are hard to break. Reading Today, 4.

Hillerich, R. L. (1982). That's teaching spelling??? Educational Leadership, 4, 615-617. 
Hodges, J. C. (1941). Harbrace handbook of English. Harcourt, Brace \& Co.

Hodges, R. E. (1982). Research update: On the development of spelling ability. Language Arts, 59(3), 284-290.

Horn, E. (1919). Principles of method in teaching spelling as derived from scientific investigation. In The eighteenth yearbook of the national society for the study of education, part II: Fourth report of the committee on economy of time in education (pp. 52-77). Public School Publishing Company.

Horn, E. (1954). Teaching spelling: What research says, for the teacher. American Educational Research Association.

Horn, E. (1967). Teaching spelling: What research says to the teacher. National Education Association. https://eric.ed.gov/?id=ED017488

Horn, E., \& Ashbaugh, E. J. (1920). Lippincott's Horn-Ashbaugh speller for grades one to eight. Lippincott. http://www.gutenberg.org/etext/33826

Horn, T. D. (1947). The Effect of the Corrected Test on Learning to Spell. The Elementary School Journal, 47(5), 277-285. https://doi.org/10.1086/462325

Jeong, A., Li, H., \& Pan, A. J. (2017). A sequential analysis of responses in online debates to postings of students exhibiting high versus low grammar and spelling errors. Educational Technology Research and Development, 65(5), 1175-1194.

https://doi.org/10.1007/s11423-016-9501-2

Johnson, R. I. (1917). The persistency of error in english composition. School Review, 26.

Johnston, F. R. (2000). Exploring classroom teachers' spelling practices and beliefs. Reading Research and Instruction, 40(2), 143-155. https://doi.org/10.1080/19388070109558339

Jones, A. C., Wardlow, L., Pan, S. C., Zepeda, C., Heyman, G. D., Dunlosky, J., \& Rickard, T. C. (2016). Beyond the rainbow: Retrieval practice leads to better spelling than does 
rainbow writing. Educational Psychology Review, 28(2), 385-400. https://doi.org/10.1007/s10648-015-9330-6

Jonge, S. D., \& Kemp, N. (2012). Text-message abbreviations and language skills in high school and university students. Journal of Research in Reading, 35(1), 49-68. https://doi.org/10.1111/j.1467-9817.2010.01466.x

Joshi, R. M., Treiman, R., Carreker, S., \& Moats, L. C. (2008). How Words Cast Their Spell. American Educator, 6-43.

Kellaway, L. (2014, November 3). Why typos and spelling mistakes don't really matter. $B B C$ News. https://www.bbc.com/news/business-29529578

Kemp, N. (2010). Texting versus txtng: Reading and writing text messages, and links with other linguistic skills. Writing Systems Research, 2(1), 53-71. https://doi.org/10.1093/wsr/wsq002

Kemp, N., Wood, C., \& Waldron, S. (2014). do i know its wrong: Children's and adults' use of unconventional grammar in text messaging. Reading and Writing, 27(9), 1585-1602. https://doi.org/10.1007/s11145-014-9508-1

Kilzer, L. R. (1926). The test-study method versus the study-test method in teaching spelling. The School Review, 34(7), 521-525. https://doi.org/10.1086/438375

Kirk, C., \& Gillon, G. T. (2009). Integrated morphological awareness intervention as a tool for improving literacy. Language, Speech, and Hearing Services in Schools, 40(3), 341-351. https://doi.org/10.1044/0161-1461(2008/08-0009)

Klein, R. (2013, August 5). Professor Sugata Mitra on teaching spelling and grammar: Phones have made it unnecessary. Huffington Post. https://www.huffpost.com/entry/sugatamitra-spelling_n_3708644 
Koerner, B. (2012, January 31). Why spelling still matters in the digital age. Wired. https://www.wired.com/2012/01/st-essay-autocorrect-rebuttal/

Kornell, N., Hays, M. J., \& Bjork, R. A. (2009). Unsuccessful retrieval attempts enhance subsequent learning. Journal of Experimental Psychology: Learning, Memory, and Cognition, 35(4), 989-998. https://doi.org/10.1037/a0015729

Kornell, N., \& Vaughn, K. E. (2016). How retrieval attempts affect learning: A review and synthesis. In B. H. Ross (Ed.), Psychology of Learning and Motivation (Vol. 65, pp. 183215). Academic Press. https://doi.org/10.1016/bs.plm.2016.03.003

Krashen, S. (2002). Whole language and the great plummet of 1987-92: An urban legend from California. Phi Delta Kappan, 83(10), 748-753. https://doi.org/10.1177/003172170208301008

Kreiner, D. S., Schnakenberg, S. D., Green, A. G., Costello, M. J., \& McClin, A. F. (2002). Effects of spelling errors on the perception of writers. The Journal of General Psychology, 129(1), 5-17. https://doi.org/10.1080/00221300209602029

Lenhart, A., Arafeh, S., \& Smith, A. (2008). Writing, technology and teens. Pew Internet \& American Life Project. Available at: https://files.eric.ed.gov/fulltext/ED524313.pdf

Leipzig, D. H. (2000). The knowledge base for word study: What teachers need to know. Scientific Studies of Reading, 11(2), 105-131.

Lin, P.-H., Liu, T.-C., \& Paas, F. (2017). Effects of spell checkers on English as a second language students' incidental spelling learning: A cognitive load perspective. Reading and Writing, 30(7), 1501-1525. https://doi.org/10.1007/s11145-017-9734-4

Liu, Z. (2004). Perceptions of credibility of scholarly information on the web. Information Processing \& Management, 40(6), 1027-1038. https://doi.org/10.1016/S03064573(03)00064-5 
Louis, R. N. (1950). A study of spelling growth in two different teaching procedures [Dissertation, Central Washington University].

Lunsford, A. A., \& Lunsford, K. J. (2008). "Mistakes are a fact of life": A national comparative study. College Composition and Communication, 59(4), 781-806.

Graham, S., Haynes, J. B., \& DeLaPaz, S. (1996). Spelling checkers and students with learning disabilities: Performance comparisons and impact on spelling. The Journal of Special Education, 30(1), 35-57. https://doi.org/10.1177/002246699603000103

Mann, H. (1839). Spelling. The Common School Journal, 1, 154-357.

Martin-Lacroux, C. (2017). "Without the spelling errors I would have shortlisted her...”: The impact of spelling errors on recruiters' choice during the personnel selection process. International Journal of Selection and Assessment, 25(3), 276-283. https://doi.org/10.1111/ijsa.12179

Martin-Lacroux, C., \& Lacroux, A. (2017). Do employers forgive applicants' bad spelling in résumés? Business and Professional Communication Quarterly, 80(3), 321-335. https://doi.org/10.1177/2329490616671310

Mazzio, F. (1987). Spelling. English language arts concept paper. Oregon State Department of Education. https://eric.ed.gov/?id=ED284264

McNaughton, D., Hughes, C. A., \& Clark, K. (1994). spelling instruction for students with learning disabilities: Implications for research and practice. Learning Disability Quarterly, 17(3), 169-185. https://doi.org/10.2307/1511072

McNeill, B., \& Kirk, C. (2014). Theoretical beliefs and instructional practices used for teaching spelling in elementary classrooms. Reading and Writing, 27(3), 535-554. https://doi.org/10.1007/s11145-013-9457-0 
Mellon, E. (2009, December 25). Some schools ditch traditional spelling tests. Houston Chronicle. https://www.chron.com/news/houston-texas/article/Some-schools-ditchtraditional-spelling-tests-1729815.php

Mitton, R. (1987). Spelling checkers, spelling correctors and the misspellings of poor spellers. Information Processing \& Management, 23(5), 495-505. https://doi.org/10.1016/03064573(87)90116-6

Moats, L. C. (2005). How spelling supports reading. American Educator, 13, 12-22, $43-43$.

Montgomery, D. J., Karlan, G. R., \& Coutinho, M. (2001). The effectiveness of word processor spell checker programs to produce target words for misspellings generated by students with learning disabilities. Journal of Special Education Technology, 16(2), 27-42. https://doi.org/10.1177/016264340101600202

Morin, A. (2020). Creative ways to help your youngster practice spelling words. ThoughtCo. https://www.thoughtco.com/ways-to-practice-spelling-words-2086716

Morris, M. R., Counts, S., Roseway, A., Hoff, A., \& Schwarz, J. (2012). Tweeting is believing?: Understanding microblog credibility perceptions. Proceedings of the ACM 2012 Conference on Computer Supported Cooperative Work - CSCW' 12, 441. https://doi.org/10.1145/2145204.2145274

Mozafari, A., El-Alayli, A., Kunemund, A., \& Fry, T. (2019). Impressions of businesses with language errors in print advertising: Do spelling and grammar influence the inclination to use a business? Current Psychology, 38(6), 1721-1727. https://doi.org/10.1007/s12144017-9735-0

Murray, D. (2015, February 8). Teachers use new methods to teach the old subject of spelling. Oakland Press. https://www.theoaklandpress.com/news/teachers-use-new-methods-toteach-the-old-subject-of-spelling/article_eccceda4-e9a9-5982-8004-513c9d7e35a6.html 
National Commission on Writing. (2004). Writing: A powerful message from state government. https://archive.nwp.org/cs/public/print/resource/2541

National Commission on Writing. (2005). Writing: a ticket to work. . or a ticket out. https://archive.nwp.org/cs/public/print/resource/2540

Numeracy Ninjas. (2015, July 26). What is Numeracy Ninjas? Numeracy Ninjas. https://www.numeracyninjas.org/?page_id=161

Oelke, D., Spretke, D., Stoffel, A., \& Keim, D. A. (2012). Visual readability analysis: How to make your writings easier to read. IEEE Transactions on Visualization and Computer Graphics, 18(5), 662-674. https://doi.org/10.1109/TVCG.2011.266

Oregon Institute of Technology. (2018). Netiquette. http://www.oit.edu/online/about/netiquette

Ouellette, G., Sénéchal, M., \& Haley, A. (2013). Guiding children’s invented spellings: A gateway into literacy learning. The Journal of Experimental Education, 81(2), 261-279. https://doi.org/10.1080/00220973.2012.699903

Pan, S. C., \& Agarwal, P. K. (2018). Retrieval practice and transfer of learning: Fostering students' application of knowledge. http://pdf.retrievalpractice.org/TransferGuide.pdf

Pan, S. C., Cooke, J., Little, J. L., McDaniel, M. A., Foster, E. R., Connor, L. T., \& Rickard, T. C. (2019). Online and clicker quizzing on jargon terms enhances definition-focused but not conceptually focused biology exam performance. CBE_Life Sciences Education, $18(4), \operatorname{ar} 54$.

Pan, S. C., Hutter, S. A., D'Andrea, D., Unwalla, D., \& Rickard, T. C. (2019). In search of transfer following cued recall practice: The case of process-based biology concepts. Applied Cognitive Psychology, 33(4), 629-645. 
Pan, S. C., Lovelett, J., Stoeckenius, D., \& Rickard, T. C. (2019). Conditions of highly specific learning through cued recall. Psychonomic Bulletin \& Review, 26(2), 634-640. https://doi.org/10.3758/s13423-019-01593-x

Pan, S. C., \& Rickard, T. C. (2018). Transfer of test-enhanced learning: Meta-analytic review and synthesis. Psychological Bulletin, 144(7), 710-756. https://doi.org/10.1037/bul0000151

Pan, S. C., Rubin, B. R., \& Rickard, T. C. (2015). Does testing with feedback improve adult spelling skills relative to copying and reading? Journal of Experimental Psychology: Applied, 21(4), 356-369. https://doi.org/10.1037/xap0000062

Pan, S. C., \& Sana, F. (2021). Pretesting versus posttesting: Comparing the pedagogical benefits of errorful generation and retrieval practice. Journal of Experimental Psychology: Applied. https://doi.org/10.1037/xap0000345.

Pan, S. C., Sana, F., Schmitt, A. G., \& Bjork, E. L. (2020). Pretesting reduces mind wandering and enhances learning during online lectures. Journal of Applied Research in Memory and Cognition, 9(4), 542-554.

Pashler, H., Bain, P. M., Bottge, B. A., Graesser, A., Koedinger, K., McDaniel, M., \& Metcalfe, J. (2007). Organizing instruction and study to improve student learning. IES Practice Guide. NCER 2007-2004. National Center for Education Research. https://eric.ed.gov/?id=ED498555

Pashler, H., McDaniel, M., Rohrer, D., \& Bjork, R. (2008). Learning styles: Concepts and evidence. Psychological Science in the Public Interest, 9(3), 105-119. https://doi.org/10.1111/j.1539-6053.2009.01038.x

Petersen, P. (2010, January 1). Letters to the editor. Houston Chronicle. https://www.chron.com/opinion/outlook/article/Letters-to-the-editor-1620532.php 
Plester, B., Wood, C., \& Joshi, P. (2009). Exploring the relationship between children's knowledge of text message abbreviations and school literacy outcomes. British Journal of Developmental Psychology, 27(1), 145-161. https://doi.org/10.1348/026151008X320507

Pratt-Struthers, J., Struthers, T. B., \& Williams, R. L. (1983). The effects of the add-a-word spelling program on spelling accuracy during creative writing. Education and Treatment of Children, 6(3), 277-283.

Puranik, C. S., \& AlOtaiba, S. (2012). Examining the contribution of handwriting and spelling to written expression in kindergarten children. Reading and Writing, 25(7), 1523-1546. https://doi.org/10.1007/s11145-011-9331-x

Putman, R. (2017). Using research to make informed decisions about the spelling curriculum. Texas Journal of Literacy Education, 5(1), 24-32.

Rankin, J. L., Bruning, R. H., Timme, V. L., \& Katkanant, C. (1993). Is writing affected by spelling performance and beliefs about spelling? Applied Cognitive Psychology, 7(2), 155-169. https://doi.org/10.1002/acp.2350070207

Rayner, K., Foorman, B. R., Perfetti, C. A., Pesetsky, D., \& Seidenberg, M. S. (2001). How psychological science informs the teaching of reading. Psychological Science in the Public Interest, 2(2), 31-74. https://doi.org/10.1111/1529-1006.00004

Read, C. (1971). Pre-school children's knowledge of english phonology. Harvard Educational Review, 41(1), 1-34.

Reed, D. K. (2008). A synthesis of morphology interventions and effects on reading outcomes for students in grades k-12. Learning Disabilities Research \& Practice, 23(1), 36-49. https://doi.org/10.1111/j.1540-5826.2007.00261.x

Reed, D. K. (2012). Why teach spelling? Center on Instruction. https://eric.ed.gov/?id=ED531869 
Rice, J. M. (1897). Futility of the spelling grind. Forum, 23, 163-172; 409-419.

Rickard, T. C., \& Pan, S. C. (2017). Time for considering the possibility that sleep plays no unique role in motor memory consolidation: Reply to Adi-Japha and Karni (2016). Psychological Bulletin, 143(4), 454-458. https://doi.org/10.1037/bul0000094

Rieben, L., Ntamakiliro, L., Gonthier, B., \& Fayol, M. (2005). Effects of various early writing practices on reading and spelling. Scientific Studies of Reading, 9(2), 145-166. https://doi.org/10.1207/s1532799xssr0902_3

Roediger, H. L., \& Butler, A. C. (2011). The critical role of retrieval practice in long-term retention. Trends in Cognitive Sciences, 15(1), 20-27. https://doi.org/10.1016/j.tics.2010.09.003

Roediger, H. L., \& Karpicke, J. D. (2006a). Test-enhanced learning: Taking memory tests improves long-term retention. Psychological Science, 17(3), 249-255.

Roediger, H. L., \& Karpicke, J. D. (2006b). The power of testing memory: Basic research and implications for educational practice. Perspectives on Psychological Science, 1(3), 181210. https://doi.org/10.1111/j.1745-6916.2006.00012.x

Rohrer, D. (2015). Student instruction should be distributed over long time periods. Educational Psychology Review, 27(4), 635-643. https://doi.org/10.1007/s10648-015-9332-4

Rosen, L. D., Chang, J., Erwin, L., Carrier, L. M., \& Cheever, N. A. (2010). The relationship between "textisms" and formal and informal writing among young adults. Communication Research, 37(3), 420-440. https://doi.org/10.1177/0093650210362465

Rowland, C. A. (2014). The effect of testing versus restudy on retention: A meta-analytic review of the testing effect. Psychological Bulletin, 140(6), 1432-1463. https://doi.org/10.1037/a0037559 
Ruan, J., \& Griffith, P. (2007). Ernest Horn (1882-1967): A pioneer in spelling research and instruction. In S.E. Israel. \& E. J. Monaghan (Eds.), Shaping the reading field: The impact of early reading pioneers, scientific research, and progressive ideas. (pp. 281306).

Schlagal, B. (2001). Traditional, developmental, and structured language approaches to spelling: Review and recommendations. Annals of Dyslexia, 51(1), 147-176. https://doi.org/10.1007/s11881-001-0009-y

Schlagal, B. (2002). Classroom spelling instruction: History, research, and practice. Reading Research and Instruction, 42(1), 44-57. https://doi.org/10.1080/19388070209558380

Schlagal, R. C., \& Schlagal, J. H. (1992). The integral character of spelling: Teaching strategies for multiple purposes. Language Arts, 69(6), 418-424.

Schoephoerster, H. (1962). Research into variations of the test-study plan of teaching spelling. Elementary English, 39(5), 460-462.

Shalash, S. (2011, November 14). Education trends: The end of the weekly spelling test. Daily Press. https://www.dailypress.com/news/education/dp-xpm-20111114-2011-11-14-dpnws-spelling-tests-banned-20111114-story.html

Shankweiler, D., \& Lundquist, E. (1992). On the relations between learning to spell and learning to read. In R. Frost \& L. Katz (Eds.), Advances in Psychology (Vol. 94, pp. 179-192). North-Holland. https://doi.org/10.1016/S0166-4115(08)62795-8

Shaw, D. M., Carlson, C., \& Waxman, M. (2007). An exploratory investigation into the relationship between text messaging and spelling. New England Reading Association Journal, 43(1), 57-62.

Sherwin, J. S. (1969). Four problems in teaching english: A critique of research. National Council of Teachers of English. 
Simonsen, F., \& Gunter, L. (2001). Best practices in spelling instruction: A research summary. Journal of Direct Instruction, 9, 97-105.

Spellbound: There's no substitute for weekly spelling tests [Editorial] (2009, December 30). Houston Chronicle. https://www.chron.com/opinion/editorials/article/Spellbound-Theres-no-substitute-for-weekly-1749986.php

Stewart, W. (2013, August 2). Spelling? My phone takes care of that. Times Educational Supplement. https://www.tes.com/news/spelling-my-phone-takes-care

Stiff, C. (2012). Watch what you write: How errors in feedback influence consumer attitudes and behavior. Journal of Internet Commerce, 11(1), 41-67. https://doi.org/10.1080/15332861.2012.650988

Struthers, J. P., Bartlamay, H., Bell, S., \& McLaughlin, T. F. (1994). An analysis of the add-aword spelling program and public posting across three categories of children with special needs. Reading Improvement, 31(1), 28-36.

Sultan, A. (2010, September 18). Districts make a mistake in dropping spelling tests. St. Louis Post-Dispatch. https://www.stltoday.com/lifestyles/relationships-and-specialoccasions/parenting/aisha-sultan/article_6ca19928-0feb-5253-b27d-8760d035139c.html

Sussman, G. L. (1998). The effects of phonologically constructed spelling on first graders' literacy development [Dissertation, Fordham University].

Tagliamonte, S. A., \& Denis, D. (2008). Linguistic ruin? LOL! Instant messaging and teen language. American Speech, 83(1), 3-34. https://doi.org/10.1215/00031283-2008-001

Townsend, A. (1947). An investigation of certain relationships of spelling with reading and academic aptitude. The Journal of Educational Research, 40(6), 465-471. https://doi.org/10.1080/00220671.1947.10881537 
Traynelis-Yurek, E., \& Strong, M. (1999). Spelling practices in school districts and regions across the United States and state spelling standards. Reading Horizons: A Journal of Literacy and Language Arts, 39(4), 279-294. https://scholarworks.wmich.edu/reading_horizons/vol39/iss4/3

Treiman, R. (2018). Teaching and learning spelling. Child Development Perspectives, 12(4), 235-239. https://doi.org/10.1111/cdep.12292

Treiman, R., \& Kessler, B. (2003). The role of letter names in the acquisition of literacy. In Advances in child development and behavior, Vol. 31 (pp. 105-135). Academic Press.

Treiman, R., \& Kessler, B. (2014). How children learn to write words. Oxford University Press.

Trubek, A. (2012, January 31). Proper spelling? Its tyme to let luce! Wired. https://www.wired.com/2012/01/st-essay-autocorrect/

Vangelova, L. (2015, February 9). How spelling keeps kids from learning. The Atlantic. https://www.theatlantic.com/education/archive/2015/02/how-the-english-language-isholding-kids-back/385291/

Varnhagen, C. K. (1995). Children's spelling strategies. In V. W. Berninger (Ed.), The Varieties of Orthographic Knowledge: II: Relationships to Phonology, Reading, and Writing (pp. 251-290). Springer Netherlands. https://doi.org/10.1007/978-94-011-0385-5_8

Varnhagen, C. K. (2000). Shoot the messenger and disregard the message? Children's attitudes toward spelling. Reading Psychology, 21(2), 115-128. https://doi.org/10.1080/02702710050084446

Venesky, R. (1980). From Webster to Rice to Roosevelt: The formative years for spelling instruction and spelling reform in the U.S.A. In U. Frith (Ed.), Cognitive processes in spelling (pp. 9-32). Academic Press. 
Wallace, R. (2006). Characteristics of effective spelling instruction. Reading Horizons: A Journal of Literacy and Language Arts, 46(4). https://scholarworks.wmich.edu/reading_horizons/vol46/iss4/3

Webster, N. (1783). A grammatical institute of the English language, part I. Harfrod, Hudson, and Goodwin. http://archive.org/details/agrammaticalins00websgoog

Westerman, G. S. (1971). Spelling \& writing. Dimensions Publishing.

Westwood, P. (2014). Teaching spelling: Exploring commonsense strategies and best practices. Routledge.

Willingham, D. T., Hughes, E. M., \& Dobolyi, D. G. (2015). The scientific status of learning styles theories. Teaching of Psychology, 42(3), 266-271. https://doi.org/10.1177/0098628315589505

Woo, E. (1997, May 29). How our kidz spel: What's the big deel? Los Angeles Times. https://www.latimes.com/archives/la-xpm-1997-05-29-mn-63715-story.html

Zesiger, P., \& de Partz, M. (1997). The cognitive neuropsychology of spelling. In C. A. Perfetti, L. Rieben, \& M. Fayol (Eds.), Learning to spell: Research, theory, and practice across languages (pp. 55-74). Lawrence Erlbaum Associates Publishers. https://doi.org/10.4324/9781410604583-9

Ziegler, J. C., Stone, G. O., \& Jacobs, A. M. (1997). What is the pronunciation for -ough and the spelling for $/ \mathrm{u} /$ ? A database for computing feedforward and feedback consistency in English. Behavior Research Methods, Instruments, \& Computers, 29(4), 600-618. https://doi.org/10.3758/BF03210615

Zutell, J. (1978). Some psycholinguistic perspectives on children's spelling. Language Arts, 55(7), 844-850. 
Table 1

Examples of School Districts or Schools That Have Eliminated Spelling Tests and Dropped

Traditional Methods of Explicit Spelling Instruction

\begin{tabular}{|c|c|c|c|}
\hline Location & School district or school & $\begin{array}{l}\text { Year changes } \\
\text { implemented } \\
\text { by }\end{array}$ & $\begin{array}{c}\text { Number of } \\
\text { schools } \\
\text { affected }\end{array}$ \\
\hline Florida, U.S.A. & Lee County & 2015 & 2 \\
\hline Kentucky, U.S.A. & Oldham County & 2011 & 1 \\
\hline Michigan, U.S.A. & Oakland Schools & 2015 & $>140$ \\
\hline Missouri, U.S.A. & Parkway, Rockwood & 2010 & 38 \\
\hline Ohio, U.S.A. & Solon City & 2001 & 3 \\
\hline Texas, U.S.A. & $\begin{array}{l}\text { Clear Creek Independent, Conroe } \\
\text { Independent }\end{array}$ & 2009 & 31 \\
\hline Virginia, U.S.A. & Newport News & 2011 & 24 \\
\hline \multicolumn{2}{|c|}{ Northwest England, U.K. Holme Community School } & 2017 & 1 \\
\hline \multicolumn{2}{|c|}{ Southwest England, U.K. Whitminster Primary School } & 2008 & 1 \\
\hline
\end{tabular}


Table 2

Evaluating the Claims of $21^{\text {st }}$ Century Spelling Skeptics

\begin{tabular}{lc}
\hline Claim & Evidence in favor \\
\hline Incorrect spelling is no longer & Spelling has been dropped \\
detrimental in various contexts & from some standardized \\
and hence need not be attended to & tests, especially in the \\
& U.S. \\
& Spelling is reportedly \\
& deemphasized in some \\
& professional contexts
\end{tabular}

Technologies that automate the spelling process reduce the need to be a good speller
Technology-driven proliferation of different ways to spell renders the concept of correct spelling obsolete
Spellcheck software has

$\sim 80 \%$ accuracy at catching incorrect spellings

Textisms and other nontraditional spellings have entered into popular use
Counterevidence

Spelling is still assessed or has been reemphasized on other standardized tests

Spelling is critical in job applications and in some promotion contexts

Spelling affects the efficacy and credibility of advertising, reviews, and websites

Spelling impacts perception of writers and their writing

Spelling may influence reading and writing skills

Spelling aids have not appreciably improved the quality of written work

Spelling aids do not often catch otherwise correctly spelled, but inappropriate, words

Spelling aids can suggest inappropriate words

Spelling aids may incorrectly handle proper nouns, capitalization, punctuation, and other aspects of writing

Text messaging behavior does not appear to strongly influence spelling skills

Most writers tend to limit their use of textisms to informal modes of communication

Proper spelling is valued in various online venues 


\section{Table 3}

Spelling Instruction According to the Horn-Ashbaugh Speller (1920)

\begin{tabular}{|c|c|c|c|}
\hline Timeframe & Day & Activity type & Description \\
\hline \multirow[t]{6}{*}{ Each week } & Monday & Lesson & $\begin{array}{l}\text { New word list is assigned. Teacher pronounces each } \\
\text { word in the list as students follow along and } \\
\text { pronounce in unison. }\end{array}$ \\
\hline & & Pretest & $\begin{array}{l}\text { Students attempt to spell each word, one at a time, } \\
\text { then exchange papers and correct each other's tests. } \\
\text { Missed words are rewritten and assigned for further } \\
\text { study. }\end{array}$ \\
\hline & Tuesday & $\begin{array}{l}\text { Word study, } \\
\text { practice testing }\end{array}$ & $\begin{array}{l}\text { 1. Look at the word and pronounce it out loud. } \\
\text { 2. Close eyes and attempt to visualize the word. } \\
\text { 3. Check correct spelling (if not, return to step 1). } \\
\text { 4. Cover the word and write it. } \\
\text { 5. Check spelling attempt (if not, return to step 1). } \\
\text { 6. Repeat steps } 4 \text { and } 5 \text { twice more. }\end{array}$ \\
\hline & Wednesday & Test & $\begin{array}{l}\text { Students are tested on the word list for that week, plus } \\
\text { a word list that was learned one month prior. The } \\
\text { words that are missed may be corrected and studied. }\end{array}$ \\
\hline & Thursday & $\begin{array}{l}\text { Word study, } \\
\text { practice testing }\end{array}$ & Repeat as on Tuesday. \\
\hline & Friday & Test & $\begin{array}{l}\text { Repeat test as on Wednesday. Words that are missed } \\
\text { are studied and the number of errors made over } \\
\text { successive tests are compared and logged in a } \\
\text { spelling notebook. }\end{array}$ \\
\hline $\begin{array}{l}\text { One month } \\
\text { later }\end{array}$ & $\begin{array}{l}\text { Wednesday, } \\
\text { Friday }\end{array}$ & Test & $\begin{array}{l}\text { The word list should be tested one month later on the } \\
\text { Wednesday and Friday of a given week (as above). }\end{array}$ \\
\hline $\begin{array}{l}\text { One year } \\
\text { later }\end{array}$ & Any & Word study & $\begin{array}{l}\text { Difficult words are reviewed at the start of the next } \\
\text { grade. }\end{array}$ \\
\hline Every year & Daily & Record-keeping & $\begin{array}{l}\text { Students should keep a spelling notebook wherein } \\
\text { they record errors made on spelling tests and in } \\
\text { written work, plus track their progress at learning } \\
\text { words. }\end{array}$ \\
\hline
\end{tabular}




\section{Table 4}

Common Contemporary Approaches to Explicit Spelling Instruction

\begin{tabular}{|c|c|c|}
\hline Approach & Objective(s) & Example learning activities \\
\hline \multirow[t]{4}{*}{ Phonemic } & $\begin{array}{l}\text { Learn meaningful units of sound and } \\
\text { sound-symbol relationships }\end{array}$ & $\begin{array}{l}\text { Segmenting words into sounds, initially } \\
\text { orally and then in written form }\end{array}$ \\
\hline & $\begin{array}{l}\text { Learn consistent letter or syllable } \\
\text { patterns }\end{array}$ & $\begin{array}{l}\text { Sorting words by letter or syllable } \\
\text { patterns }\end{array}$ \\
\hline & & Studying letter or syllable rules \\
\hline & & Use of a phonics program \\
\hline \multirow[t]{2}{*}{ Morphemic } & $\begin{array}{l}\text { Learn units of letters that carry } \\
\text { meaning }\end{array}$ & $\begin{array}{l}\text { Studying rules for pluralizing words, } \\
\text { such as by using suffixes }\end{array}$ \\
\hline & & Sorting words by suffixes \\
\hline \multirow[t]{2}{*}{ Whole word } & $\begin{array}{l}\text { Learn the spellings of entire words, } \\
\text { and particularly those that are } \\
\text { irregular }\end{array}$ & $\begin{array}{l}\text { Self-corrected test and study-copy- } \\
\text { cover-compare methods }\end{array}$ \\
\hline & & $\begin{array}{l}\text { Studying groupings of words that are } \\
\text { related in some manner, such as } \\
\text { semantically }\end{array}$ \\
\hline
\end{tabular}




\section{Table 5}

Spelling Test Types

\begin{tabular}{|c|c|c|}
\hline Type & Description & Examples \\
\hline \multirow[t]{3}{*}{ Pretests } & $\begin{array}{l}\text { Tests that occur before learning activities; used to } \\
\text { measure students' existing spelling knowledge and } \\
\text { skills }\end{array}$ & $\begin{array}{l}\text { Attempting to spell words } \\
\text { that are dictated orally }\end{array}$ \\
\hline & & Spelling inventories \\
\hline & & $\begin{array}{l}\text { The first test in the test- } \\
\text { study-test method }\end{array}$ \\
\hline \multirow[t]{2}{*}{ Practice tests } & $\begin{array}{l}\text { Tests wherein students engage in retrieval practice } \\
\text { (i.e., retrieving and applying spelling knowledge and } \\
\text { skills); used to enhance learning }\end{array}$ & $\begin{array}{l}\text { Study-copy-cover- } \\
\text { compare methods }\end{array}$ \\
\hline & & $\begin{array}{l}\text { Self-corrected test } \\
\text { method }\end{array}$ \\
\hline \multirow[t]{3}{*}{ Postttests } & $\begin{array}{l}\text { Tests that assess the outcome of instructional activities; } \\
\text { used to measure the spelling knowledge and skills } \\
\text { that students have attained }\end{array}$ & $\begin{array}{l}\text { Assessments of different } \\
\text { components of spelling } \\
\text { skills }\end{array}$ \\
\hline & & Friday spelling tests \\
\hline & & $\begin{array}{l}\text { The final test in the test- } \\
\text { study-test method }\end{array}$ \\
\hline
\end{tabular}

